\title{
THE FEDERAL FAIR HOUSING REQUIREMENTS: TITLE VIII OF THE 1968 CIVIL RIGHTS ACT
}

\begin{abstract}
A combination of economics and racial discrimination has over many years forced Negroes into unequal and inadequate housing and living conditions. The Federal Fair Housing Act of 1968 attempted to contribute to the arsenal of legislation with which the federal government hopes to eliminate the ghetto from the American scene. This comment examines this most controversial of recent civil rights laws in light of the social context from which it arose. Areas of potential difficulty in interpretation and construction of the statute are analyzed and conclusions drawn as to the probable effectiveness of the Act in relieving the social evils to which it is directed.
\end{abstract} The Housing Act of 1949 proclaimed a national goal of a family. ${ }^{1}$ Nineteen years later, it was apparent that the country was still far from realizing this ambition, ${ }^{2}$ racial inequality in housing being a particularly disturbing factor. Figures from the 1960 census revealed that forty-six percent of the non-white as compared with fourteen percent of the white urban population lived in unsound housing. In addition, twenty-five percent of urban non-whites lived in housing units with more than one person per room, as compared with eight percent of the white population living under similar overcrowded conditions. ${ }^{3}$ It appears that there was little improvement during the 1960's, and in fact, living conditions, in

\footnotetext{
' Housing Act of 1949 , ch. $338, \S 2,63$ Stat. 413. As amended and codified the Act can be found at 42 U.S.C. $\$ \S 1401-36$ (1964). The Act was passed to state a national housing objective and to provide means of achieving that objective. It provided federal aid to locally sponsored slum clearance and low rent public housing projects and financial assistance for farm housing.

=See Message from the President of the United States, H.R. Doc. No. 243, 90th Cong., 2d Sess. 8 (1968).

'Hearings on S. 1358, S. 2114 and S. 2280 Relating to Civil Rights and Housing Before the Subcomm. on Housing and Urban Affairs of the Senate Comm. an Banking and Finance, 90th Cong., lst Sess. 5 (1967) [hereinafter cited as 1967 Hearings] (remarks of Att'y Gen. Ramsey Clark).
} 
many of the country's urban areas actually worsened during this period. 4

Congress designed portions of the Civil Rights Act of $1968^{5}$ to provide a partial remedy for the distressing housing inequities which exist today and thus to enable the nation to approach its goal of a decent home and suitable living environment for every citizen. Title VIII of the $A$ t $^{6}$ represents the first Congressional attempt since $1866^{7}$ to deal effectively with racial, ethnic and religious discrimination in housing on a national level. Congressional consideration of the fair housing portions of the 1968 Act was prolonged and intensive. ${ }^{8}$ This comment examines the result of this protracted Congressional deliberation, primarily dealing with the law's probable effectiveness in advancing its stated

'See Message from the President of the United States, supra note 2, at 2.

582 Stat. 73 (codified in scattered sections of 18, 25, 42 U.S.C.A.).

1 42 U.S.C.A. $\S \S 3601-3619$ (Supp. 1969).

' See notes 119-22 infra and accompanying text.

${ }^{x}$ H.R. 2516, 89th Cong., 2d Sess. (1967) was the basic civil rights bill to which the subsequent fair housing provisions were appended. It passed the House Aug. 16, 1967 by a vote of 326-93. 113 CONG. REC. H 10,606 (daily ed. Aug, 16, 1967). The bill, after considerable amendment, passed the Senate by a vote of $71-20$ on Mar. 11, 1968) 114 CoNG. REC. S2577-78 (daily ed. Mar. 11, 1968). It then took the House another month to approve the bill as amended, passage being delayed until Apr. 10, 1968. 114 CoNG. Rec. H2825-26 (daily ed. Apr. 10, 1968). The progress of the bill through the Senate may be followed by studying changes to the Dirksen amendment to the bill. It was this amendment which eventually became the fair housing provisions of the Civil Rights Act. See 114 CoNG. REC. S2063-66 (daily ed. Mar. 4, 1968); 114 CONG. REC. S2246-50 (daily ed. Mar. 5, 1968); and 114 Cong. REC. S2464-69 (daily ed. Mar. 8, 1968).

Cloture was successfully invoked for only the eighth time in Senate history during the debate of the bill but only after three earlier attempts had failed. The first cloture motion was defeated 55-37 on Feb. 20, 1968. 114 Cong. Rec. S1458 (daily ed. Feb. 20, 1968). Debate at this early stage in its history was heated and based primarily upon fear of the bill's consequences. Sen. Thurmond lamented that "if it should become law, [it] would make it unlawful for the Ameriean citizen to sell his home to a purchaser of his choice." 114 CoNG. Rec. Si509 (daily ed. Feb. 20, 1968). The second attempt to end debate failed six days later by a vote of 56-36. 114 Cong. Rec. S1644 (daily ed. Feb. 26, 1968). The reason for its failure the second time appears to be that many supporters of the prineiples outlined in the bill wanted time to work it into more acceptable form. See the remarks of Sen. Dirksen, 114 Cong. Rec. S1629 (daily ed. Feb. 26, 1968). The third cloture motion was defeated on Mar. I, 1968 bysa vote of 59-35. 114 ConG. REC. S1972 (daily ed. Mar. I, 1968). Support was growing but the Senate apparently needed more time to reach agreement as to the final form of the bill. Debate was finally limited on Mar. 4, 1968 when the fourth cloture motion succeeded, $65-32.114$ ConG. ReC. S2035 (daily ed. Mar. 4, 1968). At that time, there were over eighty amendments still pending, both to the basic bill, H.R. 2516, and to the Dirksen amendment itself. 114 CoNG. REC. S2031-32 (daily ed. Mar. 4, 1968). 
policy within the socio-economic setting which prompted the demand for housing legislation.

\section{Causes and Effects of Racial Discrimination in Housing}

The first half of this century witnessed the transformation of

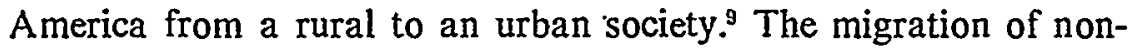
white Americans to and their subsequent confinement within urban areas is largely responsible for this shift in population. By 1960 seventy-three percent of American Negroes lived in urban areas, ${ }^{10}$ and while Negroes comprised over one-fourth of the population of our ten largest cities, they accounted for only five percent of the population in the metropolitan areas surrounding those cities." This influx of Negroes has been accompanied by an exodus to suburbia by many white city dwellers. As a result, our cities have slowly become black enclaves surrounded by white suburban rings. ${ }^{12}$ Such enclaves exist primarily because of two external forces ${ }^{13}$ - economics

'See G. \& E. GRIer. Equality and Beyond 17-19 (1966); 1967 Hearings, supra note 3. at 4 .

${ }^{10}$ See G. \& E. Grier, supra note 9, at 6-7; 1967 Hearings. supra note 3, at 4.

"Miller, Govermment's Responsibility Jor Residential Segregation, in RACE AND Property 58 (Denton ed. 1964).

is See generally The United States Comin's on Civil Rights, Civil Rights U.S.A./Housing in Washington, D.C. 32 (1962) [hereinafter cited as CiviL Rights U.S.A.1: 1967 Hearings, supra note 3, at 4, 423-24; Alsop, Matter of Fact. Washington Post, July 13,1966, $\$$, at 25, col. 1. For an intensive analysis of the formation of racial ghettos, see Report of the National Advisory Comimission on Civil Disorders 115-21 (1968).

Recently the rate at which whites are leaving the city sharply accelerated. Prior to 1966 , the average rate of exodus was 140,000 persons per year. Between 1966 and 1968, the flow increased to 500,000 per year. Although the percentage of Negro population in the city is steadily increasing, the Negro migration to the city has diminished in the past several years. In the period 1960-1966, Negro urban population increased by an average of 370,000 persons per year. Between 1966 and 1968, however, the growth rate dropped to 100,000 per year. a rate which can he attributed largely to ordinary population growth as a function of natural birth and death factors. These phenomena are accompanied by an as yet unmeasured movement by Negroes to the suburbs, giving rise not to racial integration, but to the advent of the "suburban slum-ghetto." N.Y. Times, Feb. 28, 1969, at 1, col. 1.

13 There is little doubt that the contributing factors are external to the inhabitants themselves. "[Negroes] do not reside today in ghettos as the result of an exercise of free choice ... wholly unconnected with deliberate segregation and other forms of discrimination." United States Comin' on Civil Rights, Racial Isolation in Public Schools Vol. 1, at 193 (1967). This is not to say, however, that Negroes as a group desire to integrate into white areas. There is little firm evidence on either side of the question of whether Negroes, if given their choice, would prefer to continue to live in relatively homegeneous racial groups, as long as they can live outside of slum areas. 
and racial discrimination. ${ }^{\mathrm{H}}$ The Fair Housing Act will achieve its objective of eliminating housing segregation only if it can counteract these forces, for although it is difficult to separate or to weigh the factors, ${ }^{15}$ it is clear that discrimination alone is largely responsible for present segregated housing patterns. ${ }^{16}$

To a certain degree, moral considerations initially motivated Congress' recent examination of the racially segregated housing patterns in America. Probably more important as a motivating force behind the ultimate legislation, however, was the interdependency between housing discrimination and other areas of racial injustice to which the nation had already assigned legislative priority. By 1968 it had become clear that little progress would be made in equalizing educational and occupational opportunities until racially segregated housing was eliminated. De facto school segregation is directly related to existing housing patterns. ${ }^{17}$

" 1967 Hearings, supra note 3, at 4 (remarks of Att'y Gen. Clark). The United States Commission on Civil Rights would add as a third factor to the growth and continuation of Negro ghettos the resignation to a set and patterned way of life by the ghetto inhabitants. Civit. Rights U.S.A., supra note 12 , at 5-8. While resignation and passive acceptance might well be a contributing factor to the continuation of ghetto conditions, however, it is difficult to consider such acclimation as a contributing factor to the creation of ghettos.

is 1967 Hearings. supra note 3, at 14 (remarks of Att'y Gen. Clark).

One approach that can be used to evaluate the relative importance of economics and discrimination is to assess the size of the potential Negro market for non-ghetto housing, assuming such housing to be freely available. It has been estimated that approximately sixty to seventy thousand Negro families living in Chicago, or about one-fourth of the city's Negro population, are economically capable of moving into white areas, if they were permitted to do so. Id. at 376 (remarks of Mr. James W. Cook, Pres., Leadership Council for Metropolitan Open Communities, Chicago). It is interesting to note that if this large number of Negro buyers suddenly expanded into all-white areas, the resulting dilution would produce no more than one Negro family for every fourteen white familics living in metropolitan Chicago. Id. One of the potential dificulties of the Act, however, is that this "dilution" may not occur; that in fact the legislation may serve only to transfer the ghetto to a new location and the present segregated living patterns will be continued. For a statistical analysis of the potential Negro market for non-ghetto bousing conducted by the Housing and Home Finance Agency, see id. at 316-20.

${ }^{15}$ See Civil Rights U.S.A., supra note 12, at 6 n.9; 1967 Hearings, supra note 3, at 78 . 215; Gitelman, Fair Housing in Colorado, 42 DEN. L. CEN. J. 1, 7 (1965).

"See United States Cosim'N on Civil Rights, Racial isolation in Public Schools Vol. 1. 18-20 (1967); 1967 Hearings. supra note 3, at 161 (remarks of Louis Pollack, Dean, Yale Law School). Almost ninety percent of Negro elementary school children attend schools in which over half of the student body is also Negro, Racial Isolation is PUbtic Schools, supra, Vol. 1,3-5, and the ratio of non-white to white students in city schools is steadily increasing. During the period between 1960 and 1965, the percentage of students enrolled in city schools who were Negro increased $11 \%$ in Baltimorc, 12\% in Detroit, 12\% in Chicago, 10\% in San Francisco, and 11\% in St. Louis. 1967 Hearings, supra, at 4. 
Segregated employment patterns and job discrimination also are in large part products of housing segregation. ${ }^{18}$ Thus Congress, in enacting open housing legislation, may have been providing the entire area of civil rights, ${ }^{19}$ including previous legislation, with an essential foundation.

The impact of segregated housing on other areas of national concern, however, should not overshadow its impact upon Negro housing conditions themselves. The tightly confined Negro housing areas, from which expansion or removal is very difficult, ${ }^{20}$ result in insufficient, overcrowded and unsound housing which generally costs the inhabitant far more than similar housing outside the area

is The discriminatory selectivity of the housing market has effectively barred Negroes from the expanding employment opportunities in the suburbs. E.g., 1967 Hearings, supra note 3, at $103,217-18,220$. At the same time, the number of jobs available within the inner city has been steadily decreasing. Figures provided by the National Committee Against Discrimination in Housing reveal that between 1951 and 1965 the total manufacturing and trade employment levels in five major cities shifted dramatically from the "center city" to the surrounding "ring." For example, the following cities had these rates of decrease in the city and increase in the surrounding suburban area: New York, city decrease of 129, ring increase of $120 \%$; St. Louis, city decrease of $29 \%$. ring increase of $73 \%$; and San Francisco. city decrease of $13 \%$, ring increase of $50 \%$. See 1967 Hearings, supra note 3, at 246. Further evidence of this shift in the employment market is provided by a Labor Department survey which showed that during the first half of this decade 62.5 of the industrial construction and 525 of commercial construction in the nation's metropolitan areas occurred in the suburbs. N.Y. Times, Mar. 20, 1967, at 17, col. 1. Restricting Negroes from moving into areas affording the greatest job opportunity is probably at least partly responsible for the fact that during the 1960 to 1965 period, while the national annual family income rose $14 \%$, ghetto incomes continued to decline. The income of residents of Watts (Los Angeles) decreased by S\% during this period and residents of Hough (Cleveland) suffered a 16\% decline. 1967 Hearings, supra, at 4-5.

12 "We must break the ghetto wall if success in any of the related areas is to be possible." 113 CONG. REC. 3395 (1967) (remarks of Senator Hart). By related areas, the Senator was referring to other areas of activity in the civil rights field: education, health and welfare, employment, attitudes and aspirations. See generally 1967 Hearings, supra note 3, at 133 (remarks of Jefferson Fordham, Dean, University of Pennsylvania Law School).

The lack of available housing is also an important factor in the status of Negro housing. Since 1946, only two percent of the new housing built in the nation has gone to Negroes. 113 CONG. REC. 991 (1967) (article written by Roy Wilkins of the NAACP). This low figure surely does not reflect Negro satisfaction with presently available housing, for in 1960 over twenty-five percent of the non-whites in Chicago and Los Angeles moved from one house to another within the city. R. WEAver, THE URBAN COMPLEX 231 (1964). "This shuffling of onequarter of the non-white population within some central cities represents, it seems, a desperate scramble for shelter among those who must play a game of musical chairs within a restricted housing supply continuously affected by demolition, conversion and losses for other reasons." Id. at $231-32$. 
would cost a white buyer. ${ }^{21}$ Another effect of housing segregation-the frustration of ghetto living-is the most difficult to measure but perhaps the most important. It is largely responsible, according to some analysts, for current racial unrest and rioting, ${ }^{22}$ and the psychological damage caused by this frustration is often viewed as the most destructive aspect of ghetto life..$^{23}$

Some knowledge of the causes and sources of racial discrimination is necessary in order to assess the potential success of congressional efforts to lessen the effects of such discrimination on housing conditions. While it is difficult to attribute primary responsibility to any one factor or single group of persons, ${ }^{24}$ it is possible to categorize the major sources of discrimination in housing and to isolate the apparent motivations of each.

21 This disparity apparently continues even into the moderate income levels and familics with incomes in the $\$ 7000$ range are as unable to secure decent housing as are those near the poverty level. R. Weaver, supra note 20, at 236. See also Groom, Prlces in Poor Neighborhoods, 89 MON. LAB. REV. 1085 (1966).

It is not true, however, that the high rent charged slum dwellers necessarily results in high profits to the landlord. A recent intensive study of tenement ownership in Newark, New Jersey indicates that rising vacancy rates are undermining the profitability of tenement ownership. G. SternlteB, THE TENEMENT LaNdLORd (1966). Nevertheless, while the small resident slum landlord is gradually succumbing to the financial pressures of urban renewal and decreasing profitability, there remains a group of non-resident owners who continue to specialize in large scale investments in slum property. Mandelker \& Heeter, Investment Activities of Relocated Tenement Landlords-A Pilot Study. 1968 URBan Law ANNUAL 33, 34-35.

$=1967$ Hearings, supra note 3, at 98 (remarks of Roy Wilkins of the NAACP). A sequel to the Kerner Commission Report of 1968 was released in 1969 under the title One Year Later. Sponsored jointly by the Urban Coalition and Urban America, the report states that "[A] rising proportion of Negroes in disadvantaged city areas might come to look upon the deprivation and segregation they suffer as proper justification for violent prolest or for extending support 10 now isolated extremists who advocate civil disruption by guerilla tactics."'N.Y. Times, Feb. 28, 1969, at 20, col. 1 .

2 The importance of this consideration was emphasized several years ago by the psychologist, Kenneth Clark: "It is now generally understood that chronic and remedial social injustices corrode and damage the buman personality, thereby robbing it of its effectiveness, of its creativity, if not its actual humanity... . . It is the fuel of the protests and revolts. Racial segregation, like all other forms of cruelty and tyranny, debases all human beings . . . K. KlakK, DaRK GhetTo 63 (1965).

21 "The housing industry placed responsibility on the public. Members of the public placed it on the housing industry, government, and apathy by 'others.' Representatives of the Federal Government stated that they were doing all that was within their power and indicated that the responsibility lay witb private industry and the general public." CiviL RIGHTS U.S.A.. supra note 12, at viii. 
According to the United States Commission on Civil Rights, there would be little discrimination in housing were it not for the practices and activities of the housing industry. ${ }^{25}$ Prior to 1950 , the Code of Ethics of the National Association of Real Estate Boards required that: "A Realtor should never be instrumental in introducing into a neighborhood a character of property or occupancy, members of any race or nationality, or any individuals whose presence will clearly be detrimental to property values in that neighborhood." ${ }^{26}$ Although the provision was amended in 1950 to exclude the reference to racial considerations, ${ }^{27}$ there is little doubt that most realtors still adhere to the basic thought expressed in the original provision. ${ }^{28}$ Real estate agents and brokers frequently deny that they engage in discriminatory practices and claim that, as an industry, they work diligently to place Negroes in desired housing.29 When presented with evidence of discrimination, however, the industry contends that it discriminates only because of its clients' demands. ${ }^{30}$ In addition to the alleged dictates of clients, real estate brokers find other rationales to support racial discrimination. The fear of a general decline in property value upon non-white entry into a white neighborhood is of singular importance to the agent. . $^{31}$ While some brokers parlay this fear into large profits by engaging in block-busting activity, ${ }^{32}$ others, whose commissions as agents are

$\therefore$ Id. at 15.

$\because I d$. at 12 n. 12.

"The amended provision reads: "The Realtor should not be instrumental in introducing into a neighborhood a character of property or use which will clearly be detrimental to property values in that neighborhood." $/ d$. at 12 .

$\because$ See 1967 Hearings, supra note 3, at 403. As recently as 1955, the St. Louis County Real Estate Board required that: "No member of our board may, directly or indirectly, sell to Negroes or be a party to a sale to Negroes, or finance property for sale to or purchase by Negroes, in any block, unless there are three separate and distinct buildings in such block already occupied by Negroes." St. Louis County Real Estate Board, Bulletin to All Active Members, June 1, 1955, reprinted in D. MCENTIRE, Residesce ANd RACE 241 (1960).

${ }^{3}$ See 1967 Hearings. supra note 3, at 350-51 (representatives of National Association of Real Estate Boards).

$=$ On the other hand, realtors themselves sometimes admit that this self-serving excuse is merely a rationalization made to support their own self-motivated actions. $1 d$. at 401 .

"See Horowitz, Fourteenth Amendment Aspects of Racial Discrimination in "Private" Housing, 52 CaLIF. L. Rev. I, 33 (1964). Perhaps the best evidence of the fear of lowering property values is the Code of Ethics of NAREB itself, the intent of which is clearly to avoid the possibility of such decreases. See note 27 supra.

I Blockbusting is the practice of buying from frightened homeowners at reduced prices after lirst spreading rumors to the effect that Negro entry is inevitable and disastrous to 
determined by the values exchanged in a transaction, are concerned about introducing racial disharmony into a neighborhood. In addition to declining property values, most brokers believe very strongly that they will lose business if they cannot discriminate; white homeowners, they fear, will refuse to list with them if doing so will inhibit the owners' right to discriminate. ${ }^{33}$ In addition, many individual agents are under considerable pressure from local real estate boards to hold the line against racial integration. As a result, the individual agent who personally desires to assist a Negro buyer may be precluded from doing so because of business or professional considerations. ${ }^{34}$

The real estate industry is joined by the nation's lending interests in actively discriminating in the housing area. Not only must the Negro ghetto dweller pay more than his white counterpart for equivalent housing, ${ }^{35}$ but he must also conclude mortgage and other lending agreements under far less favorable terms, assuming he can borrow at all..$^{36}$ Most lending institutions believe that nonwhite borrowers are a greater investment risk than white borrowers ${ }^{37}$ and fear that property values will decline when the number of non-whites in an area increases, thus jeopardizing their security in a loan. The cumulative effect of these "facts" often leads them to conclude that financing a non-white intrusion into a white neighborhood represents an unacceptable business risk. ${ }^{38}$

property values. The economic motive behind blockbusting can be very strong, for studies of the economic benefits accruing to brokers who engage in this practice reveal startling profits. During one period of blockbusting activity in a defined area, brokers were paying panicked whites an average of $\$ 12,000$ for their homes and shortly thereafter were selling the same houses to incoming Negroes for an average price of $\$ 20,000$. Witherspoon, Civil Rights Policy in the Federal S!'stem: Proposals Jor a Better Use of Administrative Process, 74 YALE L.J. 1171, 1207-08 (1965). Another study determined that real estate speculators engaging in blockbusting activity generally reap profits equal to double their investment on the average of every two years. G. \& E. GRIER, supra note 9, at 35.

₹ See L. Laurenti. Property halues and Race: Studies is Seven Cities 17-18 (1961); Denton, Perspectives on Race and Property, in RaCe AND Property 3, 12 (Denton ed. 1964); Wall St. Journal, June 21, 1967, at I, col. 6.

Is Many realtors were apparently coerced under threat of expulsion from their local association if they failed to "eontribute" to realtor-sponsored "forced housing" campaigns directed against state fair housing legislation. Documentary evidence of one such series of requests for funds is collected in 1967 Hearings, supra note 3, at 408-12.

"See note 21 supra and accompanying text.

${ }^{25}$ See Pitts, Mortgage Financing and Race, in RaCE AND Property 99, 107 (Denton ed. 1964).

si $1 d$. at 101.

$\approx I d$. at 101-02. See also D. McËNTIRE, supra note 28, at 218-19. 
The third corner of the housing discrimination triangle is the real estate developer and the apartment house owner. The fear of property devaluation and loss of business affect their interests much as such considerations inhibit the broker or agent. Unlike the individual homeowner or the broker, however, the developer or apartment owner's financial interest in the property continues after the individual transaction is completed. This continued involvement is primarily responsible for the belief that both reputations and profits depend to a large degree on the maintenance of racial and cultural homogeneity in their housing developments or apartment complexes. ${ }^{39}$ Such motivations are well entrenched and difficult to overcome.t0

The motives of the white homeowner in discriminating against potential non-white buyers and lessees are both more subtle and more encompassing than those of the businessman. Certainly they range beyond fear inspired by the profit motive. The average homeowner is said to believe that the introduction of non-white property owners into his neighborhood will be followed automatically by a decline in property values. ${ }^{\text {th }}$ This is the argument most often heard and frequently justified as being a rational and non-prejudicial attitude toward the problem of integrating housing. However, this belief is founded upon a myth. The most comprehensive study conducted on this problem led the investigator to conclude that the entry of non-whites into previously all-white neighborhoods most often resulted in price stability or improvement instead of price weakening. There was, he reported, no detectable or uniform influence exerted by the entry of nonwhites on property values. ${ }^{12}$

" Civil Rights U.S.A.., supra note 12, at 10-11. In 1962, shortly after President Kennedy announced his Execuive Order prohibiting discrimination in all federally assisted housing (see note $75 \mathrm{infra}$ and accompanying text), many builders reduced their operations out of fear that sales would suffer from an integration of their projects. Wall St. Journal, Dec. 28, 1962, at I, col. 6 .

${ }^{10}$ The degree to which these beliefs are held is well illustrated by the adamant refusal of a Chicago landlord to rent an available unit to a college trained Negro research technician who was employed by a large national corporation. The landlord remained steadfast in spite of the intervention on the technician's behalf by a local group of clergymen and other citizens, the chairman of the board of his employer, who offered personal guarantees, the staff of the Chicago Leadership Council, and linally the personal efforts of the Governor of Illinois. 1967 Hearings, supra note 3, at 377.

"See 1967 Hearings, supra note 3, at 84-85.

: L. LAURENTt, supra note 33, at 47. The figures used in compiling the results of the 
This fear of decreased property values produces generalized community resistance to integration which undoubtedly affects the individual property owner who is trying to sell his house and should reasionably be interested less in the neighborhood economy than he is in his own. Most homeowners, in the absence of various forms of community pressure, would probably be willing to sell to the first otherwise acceptable buyer who offered to meet the asking price, regardless of his color. If the white seller refuses such an offer, what he is really asserting, perhaps, is not his own prejudices as much as the supposed economic and social interests of his neighbors. He will, after all, be shortly removed from the area..$^{13} \mathrm{~A}$ white homeowner who is himself free of an entrenched prejudice is subjected to a number of community pressures which tend to reduce the freedom with which he personally selects his buyer. The community's apprehensions concerning the stability, social prestige and physical maintenance of the neighborhood are imposed upon the individual. Therefore, much of his reaction, in fact, may be predetermined, not so much by his own beliefs and desires to be fair, as by his social context. It would probably be inaccurate to view this sytem as one of coercion, however, because the seller may harbor sincere personal desires to do what he believes to be in the interest of his friends and neighbors and will affirmatively want to accede to their wishes. ${ }^{+1}$

author's investigation were based upon the study of ten thousand transactions over a twelve year period in seven U.S. cities. See also R. Weaver. The Negro Ghetto 293 (1948); 1967 Hearings, supra note 3 , at 39,84 . It appears that the primary cause of declining property values attendant the integration of housing, when such declines do occur, is the self-fulfilling fear of the white homeowner. Believing he is faced with a precipitous price decline, such an owner panics, sells quickly, and spawns the predicted lower price. See, e.g., G. MYrdallL. AN AMerican Dilesisia 623 (1962).

is See, e.g., Gitelman, supra note 16, at 11; Horowitz, supra note 31, at 33. While departure from the area provides an escape for the seller who is leaving town, this consideration is probably not as valid to the homeowner who is merely changing locations within the same or a nearby community. His circle of friends and neighbors would presumably remain relatively stable.

"See Rice, Bias in Housing: Toward a .Vew" Approach, 6 San. Clara Law. 162, 162.63 (1966) (quoting E.P. Conser, Exec. V.P. of NAREB, as to the many reasons why a white homeowner resists integration). Among those factors considered, several are particularly important because they suggest a kind of prejudice which is beyond the reach of legislation. These faetors are the belief that racial integration will adversely affect a homeowner's own social position; ar preference for racial and cultural similarity between his children and their friends; and a concern about the possibility of racial intermarriage. 


\section{State Fair Housing LegisLation}

The attack on racially discriminatory housing practices has not been limited to efforts by the federal government. Twenty-two states and over eighty cities and counties have enacted open housing laws. ${ }^{55}$ The scope of the state statutes is varied, ranging from the provisions in the Oregon statute which extend only to persons engaged in the selling, leasing or renting of property ${ }^{46}$ to the comprehensive coverage provided by the Massachusetts statute which prohibits discrimination in all categories of housing ${ }^{17}$ except leasing of owner-occupied two-family dwellings..$^{48}$ Of the twenty-two states with fair housing laws, only twelve include the single family home,,$^{49}$ and the statutes of only three apply to the rental of a unit

"States with fair housing statutes are: Alaska, California, Colorado, Connecticut, Hawaii, Indiana, lowa. Maine, Maryland, Massachusetts, Michigan, Minnesota, Neiv Hampshire, New Jcrsey, New York, Ohio, Oregon, Pennsylvania, Rhode Island, Vermont, Washington and Wisconsin. In addition. the District of Columbia, Puerto Rico and the Virgin Islands have each passed a fair housing statute. Major cities with fair housing ordinances are: Chicago. St. Louis, New York, Philadelphia and Pittsburgh. See, e.g., Pearl \& Terner, Fair Housing Laws: Hal/wal' Mark, 54 GEO. L.J. 156 (1965) (including a general history of state legislation and a detailed history of legislation in New York); Pearl \& Terner, Survey: Fair Housing Lasis-Design for Equal Opportunity, 16 Stan. L. Rev. 849 (1964) (including a report of the judicial reception accorded each statute on a state by state basis). For general summaries and the text of the statutes which had been enacted as of the publication of each respective source, see Library of Congress Legislative Reference Service. Fair Housing Laws, Summaries and Text of State Laws (1966) and Housing and Home Findice Agency. Fair Housing laivs Sumiaries and Text of State and Municipal LAws (1964). See also summaries and statistics prepared by the Department of Justice and HUD, 1967 Hearings. supra note 3 , at 51-72.

${ }^{10}$ The Oregon statute reads: "(1) No person engaged in the business of selling real property shall, solely because of race, color, religion or national origin of any person: (a) Refuse to sell, lease, or rent any real property to a purchaser." ORE. Rev. STAT. \$659.033 (1967).

1i for purposes of delineating the types of property subject to fair housing statutes, housing is generally categorized into four areas: public housing (housing which is provided in whole or in part by funds from a federal, state or local governmental agency); urban renewal housing (housing built on land purchased from a governmental agency as part of an urban renewal program); other publicly assisted housing (housing which is purchased or constructed with the assistance of government insured loans or mortgages): and private housing (housing provided without government assistance and owned by private persons or legal entities). See Housing and Home finance agency, fair Housing laivs - Summaries and Text of State and Municipal Laivs 8 (1964).

tx Mass. ANN. Laws ch. 151B. § 4(7) (1965). The entire Mass. statute can be found at Mass. ANN. Laws ch. 151B, \$§ l-10 (1965), as anended, ch. 15IB, \$\$ 1-9 (Supp. 1968).

15ee Alaska Stat. $\$ 18.80 .240$ (Supp. 1968); Colo. Rev. Stat. A.s. \$\$ 69-7-3(1)(d). 69-7-5(1)(b) (Supp. 1965), antending \$\$ 69-7-3(l)(d), 69-7-5(1)(b) (1964); CoNN. GEN. STAT. ANw. § 53-35(a) (Supp. 1969); Act 193, § 3-4, [1967] Sess. Laws of Hawaii 194: Iowa 
in an owner-occupied two-family house. ${ }^{50}$ While all statutes are made applicable to the practices of the real estate industry, six do not cover the lending practices of financial institutions. ${ }^{51}$

Generally, the most comprehensive of the state laws are those of Massachusetts ${ }^{52}$ and New York. ${ }^{53}$ New York, for example, provides a detailed description of the prohibited unfair housing practices, ${ }^{54}$ a complete administrative procedure to discover, investigate and impose sanctions on persons found guilty of employing discriminatory practices, ${ }^{55}$ and methods of judicial review..$^{56}$ In addition, the statute applies to discrimination by the housing industry, including both brokers and financiers. ${ }^{57}$

Most state statutes are administered by agencies which existed prior to the enactment of housing legislation. ${ }^{58}$ Each of the state laws provides for either misdemeanor fines or damages to be

CODE ANN. § 105A.13 (Supp. 1969); MASS. ANN. LAws ch. 151B, $\$ \S 1(13), 4(7)$ (1965); MinN. Stat. ANN. \$\$ 363.02(2), 363.03(2) (Supp. 1969); N.J. StaT. ANN. $\$ \$ 18.25-5(\mathrm{n})$, 18.25-12(g) (Supp. 1967); N.Y. ExEc. Law § 296-5(a) (McKinney Supp: 1968); R.1. GEN. Laws ANN. \& 34-37-4(A) (Supp. 1967); VT. Stat. ANN. tit. 13, \& 1452(a) (Supp. 1968). Michigan also apparently has provisions covering the single-family dwelling. Michigan adopted a new constitution on April 1, 1963 which established a Civil Rights Commission. The Michigan Attorney General has determined that this Commission has self-executing authority to enforce civil rights to purchase, mortgage, lease and rent private housing without further legislative authorization. Op. No. 4161, July 22, 1963, reprinted in 8 RACB REL. L. REP. 1295 (1963). The statutory procedures to be followed by the Civil Rights Commission are at Mich. STAT. ANN. $\$ \$ 3.548(1)$-(9) (Supp. 1968).

$\because$ See Alaska Stat. \& 18.80.240 (Supp. 1968); Colo. Rev. Stat. ANN. \$ 69-7-5(I)(c) (1964). There were no restrictions placed in his opinion by the Michigan Attorney General, note 49 supra, and presumably renting a two-family home in whieh the owner occupies one half is also included within the purview of the Michigan Civil Rights Commission.

"I See 1ND. ANn. STAT. $\$ \S 10-901-02$ (Supp. 1968); lowa CODE ANn. $\$ \$ 105 A . I-.14$ (Supp. 1969); ME. Rev. Stat. ANN. tit. 17. \& 1301 (Supp. 1968); N.H. Rev. StaT. ANN. $\S \S 354-A: 1$ to A:14 (1966); ORE. Rev. STAT. $\$ \$ 659.010-115$ (1967); VT. Stat. ANN. tit. 13, \$\$ 1451-53 (Supp. 1968).

5: Mass. ANN. Laws ch. 151B, §§ 1-10 (1957), as amended, ch. 151B, \$\$ 1-9 (Supp. 1968).

33 N.Y. Civ. Rights LAw $\S \S 18 a-e$ (MicKinney Supp. 1968); N.Y. EXec. LaW $\$ \$ 290-$ 301 (McKinney 1951), as antended. $\$$ 290-301 (Supp. 1968).

"N.Y. Civ. Rights Law $\S 18 b-c$ (McKinney Supp. 1968); N.Y. Exec. Law \$ 296(5) (MicKinney Supp. 1968).

s5 N.Y. EXEC. LAW $\$ 297$ (McKinney Supp. 1968).

5 Id. § 298.

${ }^{57} I d . \& 296(5)(\mathrm{d})$-(e).

ss California, for example, empowered its already funetioning State Fair Employment Practices Commission to enforce the provisions of the subsequent fair housing legislation. See Cal. Health \& Safety Code $§ 35730$ (West 1967). 
awarded to the injured complainant in a civil action. ${ }^{59}$ While each state empowers its courts to issue temporary or permanent injunctions following the establishment of probable cause of an alleged violation, few permit their administrative agencies to seek an injunction, ${ }^{60}$ and only Oregon permits such a sanction to be imposed prior to an administrative hearing which determines either probable cause or ultimate liability. ${ }^{61}$

Efforts to give the administering agencies as much latitude as possible in the scope of sanctions to be employed have met with little success in the courts. It has been held that an enabling statute may not be completely open-ended when describing the action an enforcement agency may take. ${ }^{62}$ Commissions must be definitive

52 The California provisions are typical. After the FEPC has determined that a respondent has engaged in activity made unlawful by the statute, it may: (1) order the sale or rental of the concerned property to the complainant; (2) order the sale or rental of a "like accommodation" or the next similar vacancy; or (3) if neither (1) nor (2) is available, assess damages in favor of the complainant in an amount not to exceed \$500. See Cal. HEALTH \& SAFETY CODE $§ 35738$ (West 1967).

${ }^{20}$ States in which the state agency may seek a temporary injunction are: California, Colorado. Connecticut. Hawaii. Massachusetts. Minnesota. New Jersey (Attorney General). New York and Pennsylvania. Sec Cal.H. Heal.tu \& SafiTY Conk \$ 35734 (1967); Colo. Rer. Stat. A.N. § 69-7-6(6)(b) (Supp. 1965): CoNi. Gis. Stat. A.N. § 53-36a (Supp. 1969); Act 193. $\$ 10(e)(1)$. [1967] Sess. Laws of Hawaii 194; Mass. A.x. Laws, ch.

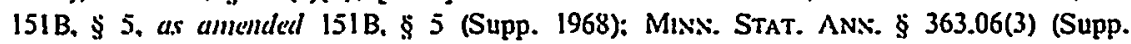
1969); N.J. STaT. ANN. § 18.25-14.1 (Supp. 1967) (Alt'y Gert:); N.Y. ExEC. LAw § 297-6 (McKinney Supp, 1968): Pa. Stat. Axx. tit. 43, \$ 959.1 (Supp. 1969).

In the case of New York, it has been judicially determined that. since the state statute provides lor such a course of action, the individual complainant is precluded from personally seeking an injunction pending the outcome of the administrative hearings. See Redd v. Zier. 229 N.Y.S.2d 582 (Sup. Ct. 1962) (not officially reported). In response to this determination. New York Attorney General Lefkowitz announced that the state would petition the courts to obtain temporary injunctions in the cases of individual complainants pending ultimate disposition by the New York State Commission for Human Rights. N.Y. Herald Tribune. July $\$, 1963$. at 2. cols. 3-5. One year later, he was able to announce his success of obtaining an order prohibiting an alleged violator from leasing the concerned premises. pending disposition of the complaint before the Commission. N.Y. Times, Apr. 16, 1964, at 24, col. 7.

"ORE. Ri:v. STAT. $\$ 659.055$. The Oregon statute provides that the filing of a complaint with the Commissioner of Labor, with subsequent notice being sent to the alleged violator, places an automatic restraint on the violator so that he is not to dispose of his property or take any action which would otherwise make the property unavailable. In contrast. and more representative, is the California statute which allows its FEPC to seek a temporary restraining order, which in no case is to be in effect for a period in excess of twenty days, only after having first determined that probable cause exists for believing the allegations in the filed complaint are true and constitute a violation. See Calif. Health \& Safety CODE $\$ 35734$ (West 1967).

'See Colorado Anti-Discrimination Comm'n v. Case, 151 Colo. 235, 250-51, 380 P.2d 34, 
when attempting to provide accommodations similar to those originally sought by the successful complainant and the order must not be so vague as to hamper good faith compliance. ${ }^{63}$

Judicial reception of state fair housing legislation has generally been favorable. The only state law that has been invalidated to date is that of Washington, where the supreme court, in $O^{\prime}$ Meara $v$. Washington State Board Against Discrimination, ${ }^{64}$ held that a state statute which prohibited discrimination in the sale or rental of publicly assisted housing was in violation of the equal protection clause of the Federal Constitution. ${ }^{65}$ The rationale of the other state courts has been that private property rights are subject to the state's police powers and that the police power for the protection of the public safety, morals and health can be properly invoked to curb discrimination, provided the legislation bears a substantial and reasonable relation to its stated purpose. ${ }^{65}$ With the lone $O^{\prime}$ Meara

42-43 (1962). The enforcement provision of the Colorado statute empowered the Commission to take "such other action as in the judgment of the commission will effectuate the purposes of this article." Colo. Rev. Stat. ANN. \& 69-7-6(12) (1963). The Colorado Supreme Court held this to be an unconstitutional delegation of legislative authority. The statute has since been amended to exclude the cited provision. Id. \$ 69-7-6(12) (Supp. 1965).

"See Massachusetts Comm'n Against Discrimination v. Colangelo, 344 Mass. 387, 400.01, 182 N.E.2d 595, 603-04 (1962) (an order to make available for rent a unit similar to that afforded "the most favored tenant" in an apartment is unnecessarily vague and incapable of enforcement).

" 58 Wash. 2d 793, 365 P.2d I (1961), cert. denied, 369 U.S. 839 (1962).

- The influence of the $O^{\prime}$ Meara case has been slight because its rationale is unclear. The statute was directed at "publicly-assisted housing" which was defined as housing subject to a federal loan or mortgage. Three of the majority of five justices believed that this classification was arbitrary and capricious and had no reasonable relation to the evil at which the statute was directed. They held that there was no justification for believing that the beneficiaries of federally approyed loans and mortgages were, as a class, a greater spource of racial discrimination than those homeowners who were subject to conventional mortgages or no mortgage at all. The classification was underinclusive and therefore in violation of the equal protection clause of the fourtecnth amendment. In contrast, the remaining two of the majority based their disapproval on state constitutional grounds. They determined that the statute in toto was violative of the ninth amendment of the Washington constitution which prohibited the taking of private property for private use. A private home. they said, was not made public and therefore outside the ambit of the constitution merely because the legislature called it public. A home remained private, in their view, with or without an FHA mortgage. See Van Alstyne. The $O^{\prime}$ Meara Case and Constitutional Requirements of State AntiDiscrimination Housing Laws, 8 How. L.J. 158 (1962); 75 HARv. L. Rev. 1647 (1962); 37 Notre Dame Laiv. 394 (1962).

${ }^{65}$ See, e.g., Burks v. Poppy Constr. Co., 57 Cal. 2d 463, 370 P.2d 313, 20 Cal. Rptr. 609 (1962); Colorado Anti-Discrimination Comm'n v. Case, 151 Colo. 235, 380 P.2d 34 (1962); State Comm'n Against Discrimination v. Pelham Hall Apts., 10 Mise. 2d 334, $170-$ 
exception, this use of the police power has been determined not to be violative of due process or equal protection if the designation of persons or property subject to the anti-discrimination provisions can be rationally justified."

It is difficult to determine with accuracy the extent to which state legislation in the housing area has alleviated the problems to which such laws are directed. A survey made in 1965 by the National Committee Against Discrimination in Housing revealed that only twelve percent of the people filing complaints under state laws were actually receiving the housing sought or comparable housing.65 It is doubtful that an aggrieved potential buyer would voluntarily submit to the rigors of the state procedural process with only a twelve percent chance of complete satisfaction. ${ }^{69}$

Two factors appear to be primarily responsible for the failure of state laws to provide an adequate remedy to the Negro who has been denied housing. One is that most state procedural systems require an excessive amount of time to reach a conclusion..$^{70}$ In addition, the inability of most state commissions ${ }^{71}$ to prevent the respondent home owner from selling or leasing the premises while the commission is considering the cașe must be viewed as a major failure of the state systems. ${ }^{72}$ "This aspect of the state-sponsored

N.Y.S.2d 750 (Sup. Ct. 1958); Porter v. Oberlin. I Ohio St. 2d 143, 205 N.E.2d 363 (1965) (city ordinance).

"See, e.g., Burks v. Poppy Constr. Co., 57 Cal. 2d 463, 370 P.2d 313, 20 Cal. Rptr. 609 (1962); Massachusetts Comm'n Against Discrimination v. Colangelo, 344 Mass. 387, 182 N.E.2d 595 (1962); Jones v. Haridor Realty Corp., 37 N.J. 384. 181 A.2d 481 (1962); Levitt and Sons. Inc. v. Division Against Discrimination, 31 N.J. 514, 158 A.2d 177, cert. denied, 363 U.S. 418 (1960).

a 1967 Hearings. supra note 3, at 16.

- Several states have reported a higher degree of success in enabling the aggrieved party to acquire the desired housing. Massachusetts, for example, was able to offer forty-three percent of complainants either the accommodations in issue or a comparable unit during the years 1958-65. See 1967 Hearings. supra note 3, at 64 . However, sixly percent of those to whom the same or comparable housing was offered refused to accept. ld. This suggests that the time required to settle claims negated the salutary effect of the favorable resolution of the claim itself.

io Wall St. Journal, June 21, 1967, at 1, col. 6. This article reaches the conclusion that the housing laws have proved easy to evade and includes descriptions of the ploys and charades used by some real estate salesmen to put of and avoid the Negro client.

"Oregon appears to be the one state whose commission is not so limited. See note 61 supra and accompanying text.

I: New York's experience has been that often after the commission had ruled in favor of a complainant, the desired home or apartment had already been leased or sold to someone 
efforts is particularly significant in view of the fact that the federal open housing law suffers from similar handicaps. ${ }^{73}$

Another major cause for the relative impotency of state legislation is that it is necessarily confined to a limited jurisdiction. Many opponents of local legislation were afraid that the existence of open housing in their area would attract minorities from surrounding jurisdictions which had no equivalent guarantees, and the limited scope of many of the state laws reflects this fear of becc ning a refuge for minority groups. ${ }^{74}$ Furthermore, the checkerboard pattern of existing laws prevents effective enforcement. Such a problem is of particular significance in an area like the District of Columbia, where many counties and two states provide varying degrees of legislative prohibition in the neighboring communities of one metropolitan area. Apparently, the presence of such difficulties and the relatively slow progress of the states were important factors leading to the federal government's action.

\section{Federal Attempts to Reduce Housing .Segregation-Title VIII}

Prior to the enactment of Title VIII of the Civil Rights Act of 1968, the federal government had made two attempts in this century to curb the growing trend of racially segregated housing. An Executive Order on Equal Opportunity in Housing, signed by President Kennedy in $1962,{ }^{75}$ was directed primarily at newly constructed housing which was subsequently financed with F.H.A. or V.A. insured or guaranteed loans. ${ }^{76}$ The Order applied only to

else. In announcing his plans to seek temporary injunctions to prohibit such results, see note 60 supra, Attorney General Lefkowitz said: "Such a situation . . . proves to be a hollow victory for the prospective tenant and underlines the nccessity of seeking the temporary injunction." N.Y. Herald Tribune, July 8, 1963, at 2, col. 3. Faced with the same prohlem and concerned that its inability to prevent a transfer of property before reaching a decision was undermining its efforts, the Colorado Anti-Discrimination Commission successfully sought injunctive authority. Gitelman, supra note 16 , at 20 . However, the procedure ultimately approved by the state legislature has been criticized as being incffective because of the excessive time required to issue an injunction. $1 d$. at 29.

3 See notes 146-50 infra and accompanying text.

"See 1967 Hearings, supra note 3, at 366-67.

a Exec. Order No. $11,063,3$ C.F.R. 652 (1959-63 Comp.).

${ }^{76}$ Sec. 101 of the Order makes it applicable to federaliy owned and operated property and to property provided in whole or in part with federal funds or federally issued or guaranteed loans. Id. 
housing not already in existence at the time of the directive, and its primary sanction, imposed upon one who discriminated in the sale, rental or financing of a covered housing unit, was to deny future federally insured funds for property financing. ${ }^{7 \pi}$ Thus, the Order had little impact upon the individual homeowner who was not concerned about future financing once he had made his sale.78

Title VI of the Civil Rights Act of $1964^{79}$ was the second major federal effort in the area of housing discrimination prior to the 1968 Act. It attempted to proscribe discrimination in programs or activities which received federal financial assistance, including within its coverage public housing and urban renewal projects. The primary sanction authorized was the withholdiug of federal funds and financial assistance to those programs or activities found to be in violation of the Act. ${ }^{80}$ Discriminatory exclusion from participation in or denial of the benefits of federally assisted programs constituted violation of the Act. ${ }^{81}$ F.H.A. or V.A. assisted contracts, however, were excluded from its provisions. ${ }^{82}$

The combined effects of these efforts by the federal government to reduce housing discrimination were negligible. Department of Housing and Urban Development (HUD) Secretary Weaver estimated that the combined coverage of both affected less than two and one-half million housing units out of a total market supply of over sixty-five million units. ${ }^{83}$

The limited impact of previous federal efforts, accompanied by evidence of the limited success of the states, induced Congress once again to consider fair housing legislation.8 ${ }^{84}$ The civil rights bill

\footnotetext{
"Another method of insuring at least partial success was the coercive action of the Department of Defense. Following issuance of the Executive Order, the Secretary of Defense directed that all leasing arrangements undertaken by the Department should contain antidiscriminatory clauses. He further ordered that only those units which were equally and fully available to all military personnel be allowed to list with base housing offices. However, this program met with only limited success in off-base housing. 1967 Hearings. supra note 3, at 90.

${ }^{23}$ See 1967 Hearings, supra note 3, at 32-33 (remarks of HUD Sec. Weaver).

72 U.S.C. $\S \S 2000 \mathrm{~d}(1-4)(1964)$.

s See id. \$2000d(1).

"see id. $\$$ 2000d.

$=1 d . \$ 2000 \mathrm{~d}(1)$.

: 1967 Hearings. supra note 3, at 32. See id. at 80, 217-18.

\&s The House had in 1966 approved H.R. 14765, the Civil Rights Act of 1966. 112 CoNG. REC. 18739-40 (1966). Title IV of that bill encompassed housing provisions similar in many respects to the scope of the 1968 leglislation. The Senate, hovever, failed to pass the bill.
} 
passed by the House in August of 1967,85 which was intended to counteract active intimidation and violence directed at persons asserting their civil rights, was comprehensively amended in the Senate to include broad fair housing legislation. ${ }^{86}$ Consideration of these amendments occupied the majority of the Senate's time during the first months of the second session of the Ninetieth Congress, ${ }^{87}$ and resulted in a statute which applies to roughly eighty percent of the national housing market. 88

The Act makes it unlawful to refuse to sell or rent a dwelling after receiving a bona fide offer, or to refuse to negotiate after the receipt of such an offer, because of the race, color, religion or national origin of the prospective buyer, ${ }^{89}$ to discriminate against any person in the terms of such sale or lease; to advertise in such a manner as to indicate a discriminatory preference; or to represent

After two motions of cloture had been defeated, 112 CoNG. Rec. 21751 (daily ed. Sept. 14, 1966), 112 CoNG. Rec. 22114 (daily ed. Sept. 19, 1966), majority leader Mansfield concluded that the sense of the Senate was clear and that further consideration was fruitless. See 112 CoNG. Rec. 22114-115 (daily ed. Sept. 19, 1966).

"See note 8 supra.

ss Senator Mondale initially introduced S. 1358, which he sought to have appended to the House-passed bill. The Mondale bill was well known to the Senate, having been the subject of hearings conducted by the Senate Subcommittee on Housing and Urban Affairs of the Committee on Banking and Currency in August, 1967. See 1967 Hearings, supra note 3. As embodied in the omnibus bill, S. 1026, it had been discussed in hearings conducted by the Subcommittee on Constitutional Rights of the Senate Committee on the Judiciary concerning the proposed Civil Rights Act of 1967, during August and September of 1967. There is no report accompanying either S. 1358 or the subsequent Dirksen amendment. See note 87 infra. The Senate Committee on Banking and Currency did not have time to take any formal action with regard to the bill before Senator Mondale felt compelled by an advancing time schedule to present S. 1358, in slightly amended form, to the Senate. Consequently, the provisions that eventually became Title VIII of the 1968 Act were considered fully only after reaching the floor of the Senate. See I14 CoNG. REC. S980 (daily ed. Feb. 6, 1968).

\&: The Mondale amendment sparked rigorous debate. It prompted Senator Ervin to refer to certain of its enforcement provisions as being "as rank a prostitution of the judicial process as has ever been put forward in this Nation." 114 CoNG. REc. S2569 (daily ed. Mar. 11, 1968). Compromise was eventually effected when Senator Dirksen, on Feb. 28, 1968, offered his substitute amendment, the progress of which can be followed through the Senate debates. See note 8 supra. From that time until passage on March 11, the Senate devoted itself to amendment. Over eighty such proposals were made and considered.

* 114 CONG. Rec. S2454 (daily ed. Mar. 8, 1968) (remarks of Senator Mondale).

; 42 U.S.C.A. \& 3604(a) (Supp. 1969). The requirement that an offer must be bona fide was added by an amendment introduced by Senator Allott. His purpose was clear: "[I] want to negate any possibility of undue harassment or pressure upon a seller or lessor." 114 CoNG. Rec. S2309 (daily ed. Mar. 6, 1968). 
to any person for discriminatory reasons that a dwelling is not available when in fact it is available. Finally, the Act makes it unlawful to engage in profit motivated "blockbusting" activities.90 The approach taken by Congress in prohibiting discriminatory practices in housing was summarized by Attorney General Clark:

[This legislation] is aimed not at privacy, but at commercial transactions. It would prohibit no one from selling or renting to a relative or to a friend. There is nothing in this bill to prevent personal choice where personal choice, not discrimination, is the real reason for action."

The anti-discriminatory provisions of the Act apply to certain dwellings owned, operated or provided by the federal government.92 As so applied, the provisions were effective at the date of enactment and extend to property covered by F.H.A. and V.A. loans. ${ }^{93}$ The 1968 Act, however, goes considerably further. Using a step-by-step graduated approach, all dwellings, subject to two important exceptions to be noted, are covered by the Act as of January 1, 1969. The three step coverage of Title VIII was adopted to cushion the impact of this extremely controversial legislation and to allow

5042 U.S.C.A. \$ 3604(b)-(e) (Supp. 1969).

21 1967 Hearings, supra note 3 , at 6.

92 42 U.S.C.A. \$ 3603(a)(1) (Supp. 1969). "Provided" refers to loans and grants from the federal government and to loans that are secured by the federal govsrnment (V.A. and F.H.A. loans). These provisions apply only to loans or agreements made after November 20 , 1962 unless such loans were completely repaid prior to the date of passage of the Act in which case the dwelling so "provided" is exempted from the section. Id. This section has recently becn interpreted as not applying to homes that are not themselves specifically subject to a federal loan or mortgage. United States v. Knippers s: Day Real Estate, Inc., Civil No. 68123 (E.D. La.. April 24, 1969) (noted in 37 U.S.L.W. 2623). Despite a strong argument by the government that homes in a subdivision which has received F.H.A. approval were contemplated by, the Act as being covered, plaintiff's memorandum in opposition to motion to dismiss at 6 , the court determined that since the houses in question were not and never had been subject to an F.H.A. or other governmental loan, the Act did not apply notwithstanding the F.H.A. "site approval." Expressly excluded from coverage are dwellings subject to a mortgage held by an institution insured by the Federal Deposit Insurance Corporation or the Federal Savings and Loan Insurance Corporation. This provision, the result of an amendment by Senator Allott, was included because the Senate believed that an FDIC or FSLIC mortgage should not be classified as a federally secured loan. 114 CoxG. REC. S2316 (daily ed. Mar. 6, 1968).

$\approx$ These provisions of the 1968 Act are identical to those of Title VI of the 1964 Act, except that F.H.A. and V.A. loans are now covered. See notes 79-8? supra and accompanying text. During the period 1961-63, roughly twenty percent of all non-farm mortgages of $\$ 20,000$ or less were secured by either the F.H.A. or V.A. Pitts, supra note 36 , at 111. 
the administrators who were to be responsible for the Act's enforcement adequate time in which to prepare their respective organizations and the public for the eventual complete imposition of the law.9.

One exclusion granted by the Act is the single unit dwelling which is sold or rented by the owner, provided such person neither owns nor has title or right to all or part of the proceeds from the sale or rental of more than three such single-family houses at any one time..$^{95}$ An owner who is not residing in the house at the time of sale, or who is not the most recent resident of the house prior to the sale, is allowed to remain excluded but only for the purpose of one sale during any two year period..$^{96}$ The exempted owner is no longer excluded after December 31, 1969 if he utilizes the services of a broker or realtor or if he advertises in a manner that can be construed under section $804^{97}$ as being discriminatory. ${ }^{98}$ The second

\footnotetext{
"See the remarks of HUD Secretary Weaver, 1967 Hearings, supra note 3, at 47. This approach, adopted for practical reasons, was severely criticized by those who believed that the urgency of the housing problem prohibitcd further delay. It was called "unfortunate and unresponsive" by Edward Rutledge of the National Committee Against Discrimination in Housing, id. at 2I4, and "unwarranted" by James Harvey of the American Friends Service Committee, id. at 432.

${ }^{2}=42$ U.S.C.A. \& $3603($ b)(I) (Supp. 1969). It is estimated that this exemption from the Act will affect approximately seven million units, or 10.8 percent of the total housing supply. 24 CONG. QTLY. ALMANAC 155 (1968).

${ }^{95} 42$ U.S.C.A. \& 3603(b)(I) (Supp. 1969). This provision was inserted by Senator Byrd to insure that a homeoswner who takes an extended vacation or leave of absence from his home and rents it in the interim remains excluded from the Act. Senator Dirksen's amendment would not have excluded a person in such a situation. See II4 CoNG. Rec. S2360 (daily ed. Mar. 7, 1968).

97 42 U.S.C.A. $\$ 3604$ (c) (Supp. 1969). Under this provision it is unlatwful to "make, print, or publish, or cause to be made, printed, or published any notice, statement, or advertisement, with respect to the sale or rental of a divelling that indicates any preference, limitation, or discrimination based on race, color, religion, or national origin, or an intention to make any such preference, limitation, or discrimination." Id.

9 42 U.S.C.A. \$3603(b)(1) (Supp. 1969). Senator Byrd proposed to exempt any private individual in the sale or rental of single family units, regardless of how many such units he ouned. He further suggested that such an individual be permitted to employ the services of a broker without losing his favored status. His purpose was to forestall an "assault upon one of the most priceless of all human rights, the right to use, manage, and to dispose of property according to one's wishes and one's own good judgment." I14 CoNG. REc. S2041 (daily ed. Mar. 4, 1968). The amendment, which would have virtually nullified the Dirksen amendment, was rejected by a vote of 38-56. Id. at \$2053. Senaor Baker then proposed to allow an individual owner, otherwise cxempt, to engage a broker and retain his excmpt status. This suggestion almost won approval, but was defeated $43-48$, primarily because it would have permitted an increase in the number of exempted sales and would have increased
} 
exception to total coverage is "Mrs. Murphy's boarding house," which provides an exemption for an owner-occupied dwelling in which fewer than four other families reside independently of each other..$^{99}$

The Act also includes within its scope real estate brokers and associations, which are prohibited from discriminating in providing access to their services and facilities. ${ }^{100}$ In addition, racial discrimination is prohibited in the granting of loans or other financial assistance and in fixing the terms of such loans when the funds so acquired are to be used for purchasing, constructing, improving, repairing or maintaining a dwelling. ${ }^{101}$

Section 810 of Title VII I ${ }^{102}$ contains the basic enforcement provisions of the Act, granting to any person ${ }^{103}$ who has been or believes he will be irrevocably injured by a discriminatory housing practice the right to file, within 180 days of the act's occurrence, a written complaint with the Secretary of the Department of Housing and Urban Development. ${ }^{104}$ The language used is permissive, not obligatory, and the complainant may forego the administrative assistance available at HUD and file a civil action in any state, local or appropriate federal district court. ${ }^{105}$

When a complaint is filed with HUD a copy must be furnished to the respondent, who may file an answer if he desires. ${ }^{106}$ The

the opportunity for an exempt individual to dispose of his property and, to that extent, defeat the purpose of the Act. See 114 CoNG. Rec. S2232, 2239 (daily ed. Mar. 5, 1968).

${ }^{93} 42$ U.S.C.A. $\$ 3603$ (b)(2) (Supṕ. 1969). This exemption releases from coverage roughly 5.5 million units, or over 8 percent of the national housing market. 24 CoNG. QTLY. ALIIA:YAC I55 (1968).

10042 U.S.C.A. \$ 3606 (Supp. 1969).

tal Id. \$3605.

vo: Id. $\$ 3610$.

${ }^{103}$ As used throughout Title Vlll, "person" "includes one or more individuals, corporations, partnerships, associations, labor organizations, legal representatives, mutual companies, joint-stock companies, trusts, unincorporated organizations, trustees, trustees in bankruptcy, receivers, and fiduciaries." Id. \$3602(d).

${ }^{105}$ Id. $\$ 3610(\mathrm{a})-(\mathrm{b})$.

${ }^{105} / d$. $\$ 3612$. As in the case of the written complaint filed with HUD, the complainant has 180 days from the date of the alleged discriminatory practice to bring his suit. $I d$. For any action brought under section 812 , the Act directs the court to "assign the case for hearing at the earliest practicable date and cause the case to be in every way expedited." Id. \$3614.

108 The first regulations promulgated by HUD which pertain to the administrative procedures to be followed under Title VIII state that the respondent will be allowed twenty days after his receipt of the complaint in which to file an answer. 34 Fed. Reg. 134 (1969). 
Secretary is then allowed thirty days in which to investigate and decide whether to take action. If the state where the alleged act occurred offers substantially equivalent rights and remedies to the aggrieved party, the Secretary's action is limited to notifying the appropriate state agencies. If the state fails to commence proceedings in thirty days, or if in the Secretary's judgment it is not acting with reasonable promptness, the Secretary may re-enter the case and continue his investigation. ${ }^{107}$ The Secretary has a subpoena power not subject to judicial review, but enforcement of a subpoena is available only upon petition to a district court. Refusal to answer the Secretary's subpoena makes a party liable to a fine of $\$ 1000$ or one year imprisonment, or both..$^{108}$

If, following receipt of a complaint or after the required thirtyday period during which an appropriate state agency has failed to take action, the Secretary decides to proceed, he is limited to the use of "informal methods of conference, conciliation, and persuasion." "I09 If HUD is unable to secure voluntary compliance within the required thirty days, the aggrieved party may, within thirty days thereafter, file an appropriate civil action. ${ }^{110}$ In such a case, the complainant having first gone to HUD, resort to a federal district court is unavailable if applicable local law provides rights "substantially equivalent" to those provided by the federal statute. If the action is brought in federal court, the statute waives the normal jurisdictional amount and establishes appropriate venue as being where the alleged discriminatory housing practice occurred or where the respondent resides or transacts his business."1 In all cases the burden of proof is on the complainant. ${ }^{112}$

The sanctions authorized by the Act include the imposition of a permanent or temporary injunction or temporary restraining order, an award of "actual damages" and a maximum of $\$ 1000$ in punitive damages. Attorney fees and court costs may also be awarded to a prevailing plaintiff if, in the court's opinion, the plaintiff is not financially able to afford such fees. ${ }^{13}$

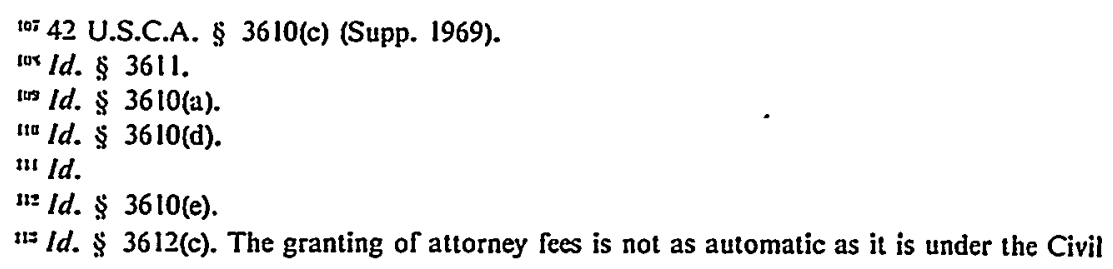


Further enforcement provisions authorize the Attorney General of the United States to proceed in a civil action against any person who, by engaging in a "pattern or practice of resistance," has interfered with the full enjoyment of any of the rights granted by Title V111.11 A civil action may also be brought against anyone who coerces, intimidates, threatens or interferes with any person engaged in the enjoyment of any of the rights granted in the antidiscrimination sections. ${ }^{115}$ This civil action provision should be read in conjunction with Title $1 \mathrm{X}$ of the Civil Rights Act, which provides a criminal remedy for similar conduct. ${ }^{116}$ Title $1 \mathrm{X}$ applies when a person, "whether or not acting under color of law, by force or threat of force willfully injures, intimidates or interferes with, or attempts to injure, intimidate or interfere with any person because of his race, color, religion or national origin" and because he is engaged in or connected with activities involving housing transactions. ${ }^{11}$ Title $1 \mathrm{X}$ also makes it unlawful to interfere with a person who lawfully is assisting or attempting to assist someone asserting his civil rights. ${ }^{118}$ Thus, Title $1 \mathrm{X}$ renders criminally liable any third person who by force or threat of force attempts to prevent either the buyer or seller from exercising his Title V111 rights or following its requirements. It should encourage the housing market to adjust to the Title Vl11 requirement of nondiscrimination without external hindrance or pressure.

Rights Act of 1964. See gencrall! Newman v. Piggie Park Enterprises, Inc., 390 U.S. 400 (1968). The requirement that fees be granted only if the prevailing plaintiff can show to the satisfaction of the court that he is financially unable to assume them was suggested by Senator Byrd. 114 Coxi. Ri:c. S2308 (daily ed. Mar. 6. 1968). By this provision. Congress apparently intended not to discourage private litigation but simply to place the awarding of fees on a more equitable footing. $l d$. (remarks of Senator Mondale). By his amendment. Senator Byrd hoped to prevent a plaintiff who had been awarded damages, possibly including punitive damages. from also receiving his expenses of litigation in cases in which he could himself afford such expenses. $I t$.

III 42 U.S.C.A. \$3613 (Supp. 1969).

ili. 1 . $\$ 3617$.

"116 ld. $\$ 3631$.

III $I d$. The causal connection must be direct and the motivation must be discriminatory. As originally worded, the House bill made it unlawful to so interfere shile a person was engaged in protected civil rights activities. The bill was amended, however, to delete while and insert because. 113 CoNo. Ri:c. H10572 (daily ed. .Iug. 16. 1967) (remarks of Rep. Celler). The "under color of law" clause was added to make it "crystal clear" that the statute applied to state officials as well as private individuals. 113 Cove. R1:C. H10514 (daily ed. Aug. 15. 1967) (remarks of Rep. Celler).

ux 42 U.S.C.A. $\$ 363 !$ (c) (Supp. 1969). 


\section{Limitations and Potential Problems of Title Vili}

The procedural complexity of Title VlII may undermine the vitality of the entire Fair Housing Act. In the normal case, it will be significantly easier to contest racially discriminatory practices under the recently revitalized Civil Rights Act of 1866 . Section one of that Act reads, in part, as follows: "All citizens of the United States shall have the same right, in every State and Territory, as is enjoyed by white citizens thereof to inherit, purchase, lease, sell, hold and convey real and personal property."119 The Supreme Court, in Jones v. Alfred H. Mayer Co., ${ }^{120}$ held that the language of that statute, now codified as section 1982 of Title 42 of the United States Code, bars all racial discrimination, public or private, in the sale or rental of real and personal property, ${ }^{121}$ and that such a proscription was a valid exercise of congressional power to enforce the thirteenth amendment. ${ }^{122}$ The rationale of the Court's decision was rather simple:

So long as a Negro citizen who wants to buy or rent a home can be turned away simply beeause he is not white, he cannot be said to enjoy the same right . . . as is enjoyed by white citizens ... to purchase [and] lease . . . real and personal property. ${ }^{123}$

It is as yet too early to determine the impact of Jones on housing discrimination, but it would appear to be significant. It seems clear that the 1866 Act provides judicial relief for racially discriminatory practices which transcends the coverage provided by Title VIII. ${ }^{124}$ Since section 1982 makes no exceptions in its

119 Now 42 U.S.C. § 1982 (1964).

1800392 U.S. 409 (1968).

I:I For a sharply different conclusion as to the intended effect of $\$ 1982$, see Avins, The (ivil Rights Act of 1s66. The (ivil Rights Bill of 1966, and the Right to Buy Properti. 40 S. CAL. L. REV. 274, 305 (1967).

is By limiting itself to thirteenth amendment considerations, the Court found it unnecessary to consider the applicability of the equal protection clause of the fourteenth amendment. 392 U.S. at 413 n.5.

121 Id. at 421. The Wall Street Journal chastised the Court after its Jones decision for reaching the "less than obvious conclusion that an amendment outlawing slavcry also permits Congress to outlaw housing discrimination." Wall St. Journal. June 20, 1968, at 16. cols. 1-2. In an unusual response, Mr. Justice Stewart answered with a letter in which hc defended the Court's decision as saying only that the law meant what it said and that Congress had the constitutional power to pass it. Wall St. Journal, July 3, 1968, at 6, col. 3 . But cf. Casper, Jones v. Maıer: Clio. Benused and Con/used Muse. 1968 S. CT. REv. 89. 99.

in' Mr. Justice Harlan recognized the potential impact of the majority decision: "In effect, 
mandate and is directed not at the transaction or the seller but at the rights of the buyer, presumably it covers those dwellings and persons specifically exempted by Title VIII. It is not, however, a complete substitute for Title VIII because, unlike the latter $r_{z}$ it does not proscribe discrimination based on religion or national origin. ${ }^{125}$ Because of the emphasis currently being placed on racial discrimination, however, it is doubtful that the "expanded" coverage of the 1968 Act will prove to be significant.1" Section 1982 also does not offer any express remedies, although the Supreme Court found this lack of express authority to be no handicap in Jones, saying that a federal court could remedy the infringement of any federally created right and enjoin discriminatory conduct even though such a sanction was not provided in the statute. ${ }^{12 \pi}$ Presumably, the allowance of damages is similarly within the discretion of the courts. ${ }^{128}$

Section 1982 does, however, afford easier access to enforcement agencies. The 1866 Act places no limitation on the accessibility of

this Court, by its construction of $\$ 1982$, has extended the coverage of federal 'fair housing' laws far beyond that which Congress in its wisdom chose to provide in the Civil Rights Act of 1968." 392 U.S. at 478 (Harlan, J., dissenting).

is It is also arguable that the 1866 Act does not apply to "blockbusting" and discriminatory lending practices. Such a limitation was suggested by the Supreme Court in the Jontes case, 392 U.S. at 413 . The Justice Department, however, takes a contrary position. It maintains that Jones stands for the proposition that section 1982 prohibits the sale of property which in any way discriminates between Negro and white buyers and that this prohibition encompasses discriminatory financing and prices. See Brief for United States as Amicus Curiae, n.4 at 9-10. Contract Buyers League v. F. \& F. Investment, No. 69-C-15 (N.D. Ill. filed in Mar. 1969).

${ }_{1=0}$ During its consideration of the fair housing bill, Congress had very little evidence placed before it that indicated the existence of discrimination based on religion or national origin. The debates and hearings pertaining to the 1968 Act are devoted almost exclusively to consideration of racial discrimination. It appears. therefore, that the Act's prohibition of religious discrimination and discrimination based on national origin was included primarily to conform with prior civil rights legislation. The major federal civil rights laws proscribe discrimination based on race, color, religion or national origin. See Civil Rights Act of $1957 \S 104(a), 42$ U.S.C.A. \$ 1975(c) (1964) (voting rights); Civil Rights Act of $1964 \$ 201(a), 42$ U.S.C. $\$ 2000 a(a)$ (1964) (public accommodations). $\$ 301(a), 42$ U.S.C. $\$ 2000 b$ (a) (1964) (public facilities), $\$ 407$ (a), 42 U.S.C. $\$ 2000 \mathrm{c}-6$ (a) (1964) (public education), $\$ 703,42$ U.S.C. $\$ 2000 \mathrm{e}-2$ (a) (1964) (equal employment opportunity, adding sex as a prohibited basis of discrimination).

$1=392$ U.S. at 414 n.13.

18 See generally J.l. Case Co. v. Borak. 377 U.S. 426 (1964); Bell v. Hood, 327 U.S. 678, 684 (1946): Note. Implying (iivil Remedies Jrom Federal Regulatory Siatutes, 77 HaRv. L. Rev. 285 (1963). (J. Wyandotte Transp. Co. v. United States, 389 U.S. 191, 201-04 (1967): Kardon v. Nat'I Gypsum Co., 73 F. Supp. 798, modified 83 F. Supp. 613 (E.D. Pa. 1947). 
the courts, whereas the 1968 Act apparently extends federal jurisdiction only to those persons who have not first gone to HUD, unless their state does not offer substantially equivalent rights. The language of the statute is not clear with respect to whether a complainant who has filed a complaint with HUD is temporarily precluded from resorting to the judiciary for relief. Although section 810 is merely permissive, section 810 (d), in speaking of when an aggrieved party may resort to the courts, refers to the necessity of waiting until HUD has determined that it will be unable to achieve voluntary compliance. Sections 810 and 812 , when read together, apparently allow an aggrieved party to go either to HUD or to the courts. If he goes to HUD first, time must be allowed for voluntary compliance by the respondent before the complainant may take his case to the judiciary. Members of the House believed this to be the proper interpretation of the Senateapproved bill..$^{29}$ The 1866 statute, therefore, provides a viable alternative to the administrative assistance made available by the more recent Act, and it will apply in more situations, permitting redress against discriminatory practices which are exempted by Title Vlli.

In contrast to the simplicity of language in section 1982, the complexity of Title VIII will undoubtedly create problems in construction and application. Section 807 expressly exempts from coverage the sale or rental by a religious organization to one of its own members of a dwelling it owns or operates for other than a commercial purpose. ${ }^{130}$ The exemption remains valid unless the organization itself discriminates on the basis of race, color or national origin in determining its membership. Also exempted is a private club, whose membership may be restricted, when it provides lodgings to its members, provided such accommodations are operated for a non-commercial purpose as an incident to the club's primary purpose. ${ }^{131}$ Such a club is authorized to give preference to its own members to the exclusion of non-members.

Religious organizations were exempted apparently to allow

129 See 114 CONG. Rec. H2765, 2817 (daily ed. Apr. 10, 1968). Sies also Nole, Discrimination in Emplorment and in Housing: Private Eifforcement Provistons of the (ivll Rights .Acts of 1964 and $1968 \%$ ). 82 HARV. L. Rtv. 834, 838-59 (1969).

${ }_{1=0} 42$ U.S.C.A. $\$ 3607$ (Supp. 1969).

ind $/ d$. 
religious freedom in the operation of such facilities as retreats, orphanages and homes for the aged. ${ }^{132}$ The private club exemption, however, is not so readily justifiable and it may be that this exemption is merely one of the numerous concessions made to gain sufficient support to pass the law. The private club exemption follows the wording of the Civil Rights Act of 1964, ${ }^{133}$ and the legislative intent associated with the 1964 Act provides a useful tool in interpreting the 1968 provisions. ${ }^{13}$ Emphasis should be placed on the words "in fact" as they appear in the excluding provision. Before a club may qualify for exempted status, its membership must in fact be restricted to applicants satisfying established qualifications. In addition, the criteria for acceptance must be based upon some objective standard other than race, for a club whose membership is determined solely by race is not the kind of organization Congress intended to exclude. While racial segregation might result from adherence to objective standards, such a result must not be directly caused by a series of sham qualifications the only purpose of which is to attain racial separation. ${ }^{135}$

Commercial advertisers and publishers may find it easy to evade the advertising provisions of the 1968 Act. ${ }^{136}$ Real estate advertising need not resort to phrases such as "restricted" or "white only" to convey to the reader that those in the area desire it to remain a white neighborhood. Such terms as "with club

12 See 1967 Hearings, supra note 3, at 365:

IF The exception to the public accommodations provisions of the Civil Rights Act of 1964 is provided as follows: "The provisions of this subchapter shall not apply to a private club or other establishment not in Jact open to the public . . ." 42 U.S.C. \$ 2000a(e) (1964) (emphasis added). The 1968 statute provides that it shall be inapplicable to "a private club not in jact open to the public ... . 42 U.S.C.A. \$ 3607 (Supp. 1969) (emphasis added).

Ist In 1964, Senator Humphrey explained in reference to the 1964 Act that " [W]e intend to protect the genuine privacy of private clubs ... whose memhership is genuinely selective on some reasonable basis." 110 CoNG. REC. 13697 (1964).

i2 See 114 Cong. Rec. S2320-21 (daily ed. Mar. 6, 1968) (remarks of Sen. Long). See generally Witherspoon, supra note 32 , at 1188 . The Supreme Court recently held that an amusement and recreation area was not a private club within the exclusionary provision of the 1964 Civil Rights Act merely because it charged a 25 cent annual "membership fee" to those people who were admitted to the grounds. Such subterfuge. it said, would not dissuade the Court from finding the area to be a public accommodation and subject to the nondiscrimination prohibitions of the 1964 Act. Daniel v. Paul, 395 U.S. 298 (1969). The Court intimated that it will view with suspicion any "club" that is a profit motivated business which is neither owned nor operated by its members. Id. at 301 .

${ }_{125}$ See note 97 supra. 
membership you become eligible to buy" or "conventional mortgages only" may connote the same idea to the more sophisticated reader. If the advertising provision is to have any force at all, the courts will have to examine subtle overtones of the techniques used to convey discriminatory preferences and pay little attention to the actual words used. Any advertising which suggests that occupancy may be dependent on factors other than ability to pay the stated price should be suspect. In addition, the actual stringency of the requirement that to remain excluded the individual homeowner must not advertise in a discriminatory manner can be questioned. First, it should be noted that advertising is not disallowed; it is only advertising that "indicates any preference, limitation, or discrimination based on race, color, religion or national origin" which is prohibited. ${ }^{137}$ Second, the individual homeowner loses his exempted status only if he so advertises "after notice" that his action is in violation of the statute. ${ }^{138}$ The Act is silent as to what constitutes notice or by whom notice.can be given. It seems in accord with the principles upon which the exemption is based to construe "notice" as more than a questioning glance from a neighbor. However, if this analysis is correct, the provision's vitality is seriously weakened, for it is difficult to imagine HUD representatives scrutinizing the real estate market pages in every local newspaper. For this reason, courts should give a liberal construction to the notice requirement. Conceivably, all that is required is that the advertiser be informed that his conduct is possibly in violation of the Act. Presumably the intent of Congress in providing the notice requirement was to prevent an unknowing and innocent violation by a good faith seller. This intent would be served by permitting notice to be given by any source whose reliability or objectivity would lead a reasonably prudent person to re-examine his actions. Such an interpretation would also serve partially to close what appears to be a serious loophole in the Act's otherwise extensive coverage. If it could be shown that the advertiser knew at the time that his conduct fell within the purview of the Act, formal notification should not be required.

It has been maintained that a single-family dwelling which was privately owned would not be exempt, even if satisfying the

13 i 42 U.S.C.A. $\S 3604$ (c) (Supp. 1969).

12x $/ d . \$ 3603(\mathrm{~b})(1)(\mathrm{B})$. 
exclusion requirements, if the house were subject to a government secured loan at the date of the enactment of Title VIII. ${ }^{139}$ However, section 803(a), which brings dwellings subject to government insured or guaranteed loans within the coverage of the Act, is expressly made subject to subsection (b) of 803 which excludes the qualifying private owner from the prohibitions of the statute. Thus, it seems that a single-family, privately owned house which meets the exclusion provisions of the statute is absolutely exempted, regardless of the origin or security of its financing.

The requirement that the families residing in "Mrs. Murphy's boarding house" live "independently" of each other may be troublesome to the courts. The Act does not define "independently," nor does it specify with what degree of independence the families must be living for the rooming house to qualify for excluded status. Arguably, several families in a boarding house which provides common kitchen facilities or meals, or sanitary facilities, are not in fact living independently of each other. Congress intended, however, to exempt the small rooming house because of the proximity in which the inhabitants live. ${ }^{150}$ Thus, the boarding house which provides common facilities would seem to have strong support for its exempted status, and the requirement of independence should be read as looking not to the extent of the physical separation of the boarders but rather to their economic independence and lack of familial relationship.

Real estate salesmen will find compliance with the law difficult for other than purely economic reasons. Most real estate agents view their association with clients as involving a strict agency relationship. Although the Act makes no provision for the broker who is advised by his client to accept offers only from whites, congressional intent in this situation is clear when the Senate's rejection of two amendments is considered. The first amendment would have allowed an otherwise exempt individual to use the facilities and services of salesmen without losing his exempted status. ${ }^{141}$ This amendment was offered on the ground that not to provide for this alternative would exact a harsh penalty upon the

I: Morris \& Powe, Constitutional and Statutory Rights to Open Housing, 44 Wash. L. REv. 1, 78, 79 (1968).

"See 114 CoNG. Rec. S1022 (daily ed. Feb. 7, 1968) (remarks of Senator Mondale).

II See 114 Cosg. Rec. S2232 (daily ed. Mar. 5, 1968). 
real estate industry. ${ }^{142}$ A second rejected amendment would have exonerated any agent who violated the Act but did so only because he was following the instructions of his client. ${ }^{133}$ While a broker who knows his white client is not going to sell to a non-white buyer would be justified in simply not bothering to show that particular home to a prospective Negro buyer, representations to the effect that an otherwise available home is not available to a Negro are prohibited. Congress apparently declined to protect the real estate industry in such situations because the result would be that the individual could screen his own discriminatory preference behind the shield of the salesman's agency.

A major failing of the Act is its disregard of fundamental methods such as zoning laws or building codes which presently are being employed to effect de facto segregation. Such local ordinances are often geared to the income levels of the inhabitants, and the restrictions they impose directly inhibit the movement of low income groups into settled high income areas. ${ }^{\text {Is }}$ Title VIll will do little for the Negro who has an annual income of $\$ 5000$ and wants to move to a particular town if its zoning laws permit only two story homes on a minimum of two acres of land. Senator Proxmire has suggested that the federal government seek to prevent this type of segregation by denying certain federal grants to areas whose zoning laws prohibit the arrival of low income groups. ${ }^{1 / 5}$

However, the most important weakness of Title VIII is the complete lack of enforcement authority given to HUD. ${ }^{140}$ Similar restraints upon state commissions have proved to be a primary factor in the relatively slow progress realized throughout the state

182 Id. at $\mathrm{S} 2239$.

"w See 114 Cong. ReC. S2325 (daily ed. Mar. 6, 1968); S1022 (daily ed. Feb. 7. 1968).

"see Aloi, Goldberg \& White, Racial and Economic Segregation by. Zoning: Death Kinell for Home Rule? I U. TOL. L. Rev. 65, 74-80 (1969); Morris \& Powe, slipra note 139, at 12: 1967 Hearings. supra note 3 , at $217,416$.

1251967 Hearings, supra note 3 , at $176,177$.

${ }^{16}$ An exchange between Senator Mondale and Attorney General Clark is particularly interesting in retrospect:

Mondale: "Unless you can move quickly with injunctive powers, the particular sale at issue will have been consummated, and it will only be after that that you can get to the merits in a trial in a district court.

Thus, 1 think injunctive powers are very important. Would you agree to that?"•

Clark: "I would certainly agree with the statement that injunctive powers are most important. Ther are critical to the effective enforcement of the lau." 1967 Hearlings. supra note 3 , at 15-16 (emphasis added). 
systems. ${ }^{\mathrm{i}}+\bar{\tau}$ As originally submitted, the fair housing bill gave HUD the power to issue both temporary restraining orders and permanent cease and desist orders. ${ }^{148}$ But as enacted, the Act limits HUD to informal persuasion-in spite of the evidence before Congress that one of the main reasons for the ineffectiveness of the Executive Order on Equal Opportunity in Housing ${ }^{1+9}$ was a lack of available administrative machinery to provide immediate relief for the complainant. ${ }^{150}$ The significance of this weakness in Title VIII cannot be over-emphasized, for if an injured party has little hope of obtaining the desired house by approaching HUD, there is little motivation for him to go through the process of filing a complaint.

The only other course of action available to an aggrieved party is to bypass HUD and proceed directly in a federal district court. A preliminary injunction would be well tailored to the needs of a person confronted with the probability that the house he desires will no longer be available at the conclusion of administrative or judicial proceedings. The issuance of such an injunction is predicated initially upon the ability of the movant to show that he will be irreparably injured pendente lite if such an order is not made. ${ }^{15 t}$ The criteria most often adopted by the federal courts are the injury to the claimant if an injunction is not issued and the possible harm to the opposing party if an injunction is granted..$^{152}$ The scale thus balanced will then be influenced by the probability of the movant's eventual success on the merits. ${ }^{153}$ When the discriminating seller is an individual homeowner, an injunction is perhaps justified. Subsequent inability to acquire the desired home should satisfy the requirement of irreparable harm. The question becomes more difficult when the seller is owner of a two hundred unit apartment complex, for it is more probable that a victorious

\footnotetext{
"'T See note 72 supra and accompanying text.

us S. 1358, 90th Cong.. Ist Sess. \& 11 (1967).

's' See note 75 supra and accompanying text.

tso See 1967 Hearings, supra note 3, at 81.

is See. e.g. Symington Wayne Corp. v. Dresser Indus., Inc., 383 F.2d 840 (2d Cir. 1967); Ikirt v. Lee Nat'l Corp., 358 F.2d 726 (3d Cir. 1966); Continental Oil Co. v. Frontier Ref. Co., 338 F.2d 780 (10th Cir. 1964); Frederick Chusid \& Co. v. Marshall Leeman \& Co., 279 F. Supp. 913 (S.D.N.Y. 1968).

15: See, e.g., Dino DeLaurentiis Cinematografica, Sp.A. v. D-150, Inc., 366 F.2d 373 (2d Cir. 1966); I kirt v. Lee Nat'l Corp., 358 F.2d 726 (3d Cir. 1966); General Time Corp. v. Talley Indus., Inc., 283 F. Supp. 832, 833 (S.D.N.Y. 1968); O'Connell v. Erie Lackawanna R.R., 268 F. Supp. 397, 405 (S.D.N.Y. 1967).

iss Id.
} 
claimant will be able to acquire similar, if not identical, housing. ${ }^{154}$ It can be argued that such a probability would preclude showing irreparable damage. Therefore, the courts might be urged to take a broader view of the irreparable harm requirement, for it is probable that fear of a temporary injunction is the very threat most likely to achieve compliance on the part of most apartment owners. This is particularly true when one considers that the $\$ 1000$ limit on punitive damages may be of little value in restraining the practices of the large apartment complex developer. So long as the developer can remain in business and rent to whom he pleases, it is doubtful that he would submit to the arguments of an aggrieved person or HUD. His basic motivation will be to forestall the imagined commercial consequences of integration. Against this background, courts should be hesitant to pass over the request for a preliminary injunction without careful consideration of the consequences to the effectiveness of the Act as well as to the individual movant.

Correlative to this point is the fact that the procedural requirements and limitations of the Act place great obstacles in the path of a complainant who first goes to HUD. Not only is such a, person denied immediate access to the federal courts, ${ }^{155}$ but he is also in some cases denied federal judicial protection entirely. ${ }^{156}$ These procedural difficulties, coupled with HUD's lack of coercive authority, raise serious doubts as to the role the department can play in the Act's enforcement.

The extent to which Title VIIl has pre-empted state statutes dealing with similar subject matter is unclear. The Act does state that it is not intended to pre-empt existing state law if that law provides "the same rights as are granted by ths [sic] subchapter." 157 In addition, a complainant who has first approached HUD may not later bring a civil action in a federal court if he has a judicial remedy under a state or local law which provides rights which are

\footnotetext{
is In the Jones $v$. Mayer case, the plaintiffs were not able to obtain the desired housing because by the time the Supreme Court granted relief, the subdivision in which they had been refused housing was completely filled. See Casper, supra note 123, at 95-96. However, future plaintiffs should be subjected to less delay, even without the aid of an injunction, than the more than two years during which the Joneses were involved.

${ }^{135}$ See note 129 supra and accompanying text. In contrast to the delays imposed by the Act on the complainant who first goes to HUD, an aggrieved party who proceeds directly to court is entitled to expeditious handling of his case by the court. See note 105 supra.

tos See note 110 supra and accompanying text.

1542 U.S.C.A. \$ 3615 (Supp. 1969).
} 
services between black ghetto and white non-ghetto areas falls within the prohibitions of the equal protection clause of the fourteenth amendment. ${ }^{167}$

The only remaining problem is whether Congress has the authority to deal with purely private action that interferes with fourteenth amendment rights. In United States $v$. Guest ${ }^{168}$ a majority of the Court apparently answered that question in the affirmative despite assertions that the case dealt only with a question of statutory construction and not congressional power..$^{169}$ The principle opinion in Guest, delivered by Mr. Justice Stewart, renewed the Court's allegiance to the state action concept. ${ }^{170}$ It went on to say that in measuring the degree of state involvement there is no requirement that state action be "exclusive or direct" and, indeed, might even be "peripheral" to the activity complained of. ${ }^{172} \mathrm{Mr}$. Justice Stewart was careful to point out, however, that the case required "no determination of the threshold level that state action must attain in order to create rights under the Equal

167 See Justice Department brief in support of federal fair housing legislation, 1967 Hearings. supra note 3 , at 8-14. In support of its contention that the benefits of government are less available in ghettos, the government relied on authorities which show that public education, public transportation, the enforcement of building and housing codes, hospital facilities and law enforcement are each less available to the ghetto resident than to the rest of the population. Id. See generally Abascal, Municipal Services and Equal Protection: Variations on a Theme by. Griffin v. Illinois, 20 HAST. L.J. 1367, 1367-68, 1382-87 (1969).

${ }_{18 x} 383$ U.S. 745 (1966).

${ }^{105} 383$ U.S. at 749, 755 (Stewart, J., for the Court); id. at 762 n.l (Harlan, J., dissenting in part).

is Id. at 755.

iid.

17: Id. See Reitman v. Mulkey, 387 U.S. 369 (1967). The Court affirmed the decision of the California Supreme Court in Mulkey, v. Reitman, 64 Cal. 2d 529, 413 P.2d 825. 50 Cal. Rptr. S8I (1966), that the popularly passed California referendum, Proposition 14, which declared the state to be "neutral" in the area of fair housing, was sufficient state action to bring it within the prohibition of the fourteenth amendment. By repealing existing state statutes, the Court said, the referendum effectively encouraged racial discrimination. The history and importance of this case has been the subject of numerous articles. See. e.g. Black, Foreword: "State Action." Equal Protection. and California's Proposition 14. 81 HARv. L. Rev. 69 (1967); Horowitz \& Karst, Reitman v. Mulkey: A Telophase of Substantive Equal Protection, 1967 S. CT. REv. 39; Horowitz \& Karst, The Proposition Fourteen Cases: Justice in Search of a Justification, 14 U.C.L.A.L. Rev: 37 (1966); Miller, Mulkey v. Reitman: A Brave But Futile Gesture? 14 U.C.L.A.L. Rev. 51 (1966); Williams, Mulkey v. Reitman and State Action, 14 U.C.L.A.L. REv. 26 (1966); 65 MICH. L. Rev. 777 (1967); 14 U.C.L.A.L. REv. I (1966); 20 VAND. L. Rev. 1346 (1967). See also Hunter v. Erickson, 393 U.S. 385 (1969); Spaulding v. Blair, 403 F.2d 862 (4th Cir. 1968); 1969 Dexte L.J. 185. 
Protection Clause." "1733 Others on the Court felt no similar restraint. Justices Brennan and Clark each apparently concluded that section 5 of the fourteenth amendment empowered Congress to enact legislation to prevent a denial of fourteenth amendment rights even if state action in no form was responsible for the denial. ${ }^{174}$ Their concurrences, representing the opinions of six members of the Court, suggest the constitutionality of legislation such as Title VIII which reaches the private action of individuals. ${ }^{155}$

Finally, limited support for the fourteenth amendment position is supplied by one interpretation of Jones $v$. Alfred H. Mayer Co., ${ }^{176}$ which suggests the persuasion of the Court at the time of that decision. The Jones case dealt with the constitutionality of portions of the Civil Rights Act of 1866 and was decided on thirteenth amendment grounds. The fact situation involved racial discrimination in housing, but the Court discussed Title VIIl only as was necessary to show its inapplicability to that case. ${ }^{17 \pi}$ In doing so, however, the language used presumed the constitutionality of Title VIII, and the Court treated the Act, which had been passed only several months earlier, as an existing and viable statute the impact of which would be significant.

Additional support for the constitutionality of the Act is provided by the commerce clause of the Constitution. Discrimination in housing and the resultant confinement of Negroes within older homes in ghetto areas reduces to an indeterminate extent the market demand for new homes and the interstate movement of this market. The impact of these consequences on interstate commerce, however slight, is probably sufficient to justify congressional intervention to protect the housing industry. Congressional power under the commerce clause

\footnotetext{
1 is United States v. Guest, 383 U.S. 745, 756 (1966).

iat Justice Clark, with Justices Black and Fortas joining, said: "[There now can be no doubt that the specific language of $\$ 5$ empowers the Congress to enact laws punishing all conspiracies-with or without state action that interfere with Fourtcenth Amendment rights." Id. at 762. Justice Brennan, joincd by the Chief Justice and Justice Douglas, suid: "Section 5 authorizes Congress to make laws that it concludes are reasonably necessary to protect a right created by and arising under that Amendment; and Congress is thus fully empowered to determine that punishment of private conspiracies interfering with the excrcise of such a right is necessary to its full protection." Id. at 782.

153 See Cox, supra note 166, at 103; Morris \& Powe. stupra note 139, at 42, 57-58.

176392 U.S. 409 (1968).

iis Id. at 413-17.
} 
"substantially equivalent" to the rights recognized in the Act.158 However, it is difficult to determine, for example, if a state law exempting five-family boarding houses is "substantially equivalent" with Title VIII, which exempts only a four-family boarding house. Congress apparently intended for the pre-emption provisions to be read as liberally as possible, allowing state laws to prevail until they proved inadequate to accomplish the stated purpose of the Act. ${ }^{159}$ It seems clear, however, that existing state laws should be subject to federal pre-emption to the extent that they fail to provide effective redress or administrative assistance to a person who would have such opportunity under Title VIll. Some support for this view is provided by section 815 , which declares invalid any state law which permits any discriminatory housing practice prohibited by the federal statute. State legislation which does not prevent discrimination by financial institutions, the real estate industry or the individual homeowner should be particularly suspect, because it is these institutions whose interests tend to support the status quo and whose collective efforts dominate the housing market. The federal courts and HUD should, therefore, be concerned not so much with the available remedies and procedures under similar state legislation as with the state law's effectiveness in securing desired housing for persons to whom such housing would be available under Title VIII.

The constitutionality of Title VIIl will probably be affirmed as soon as the question reaches the courts. In 1967 Attorney General Clark proclaimed that he had "no doubt as to the constitutionality of the [fair housing] bill."'160 Congress based the constitutionality of

${ }^{15 x} / d$. $\$ 3610$ (d). This provision has been interpreted by at least one district court as limiting federal jurisdiction to those cases in which the plaintiff clearly has no available remedy under state law. See Colon v. Tompkins Square Neighbors, Inc., 289 F. Supp. 104 (S.D.N.Y. 1968). See also 82 HARv. L. Rev. 834, supra note 129, at 840-45.

13 See, e.g., 114 CoNG. REC. S2456-57 (daily ed. Mar. 8, 1968) (exchange between Senators Dominick and Javits).

1601967 Hearings, supra note 3, at 7. Attorney General Clark argued that "Congress has the constitutional authority and duty to remove whatever it reasonably considers to be a barrier to equal protection of the law, even if the barrier is a product of individual action." Id. at 6 . See the brief prepared by the Justice Dept., id. at \$-14. This statement, of course, has not gone unchallenged. "[T]here is not the slightest shadow of constitutional justification for a federal law simply prohibiting housing discrimination in general." Rice, supra note 44, at 165. The Senate found itself equally divided. "Under no theory of either the commerce clause or the fourteenth amendment do I find constitutional authority to deprive any individual of his basic, inherent right to hold, use and enjoy private property." 114 CoNG. 
the fair housing bill on both the equal protection clause of the fourteenth amendment and the commerce clause. ${ }^{161}$ The fourteenth amendment clauses provide strong support to the assertion of constitutionality and three Supreme Court decisions in 1966 and one in 1968 lend themselves directly to these constitutional considerations.

In Katzenbach v. Morgan ${ }^{162}$ the Court was called upon to determine the constitutionality of the Voting Rights Act of $1965 .^{163}$ Echoing its pronouncements in South Carolina v. Katzenbach, ${ }^{164}$ which had been decided earlier in the year, the Court affirmed its position with respect to the criteria to be employed in weighing the authority of Congress under the fourteenth and fifteenth amendments. Section 5 of the fourteenth amendment, it said, gave Congress broad powers whose reach was curtailed only by the legitimacy of the legislation and by its appropriateness to the objects envisioned by the amendment. ${ }^{165}$ The combined rationales of the South Carolina and Morgan cases suggest that Congress may use any rational means to effectuate the constitutional prohibitions of the fourteenth and fifteenth amendments, ${ }^{166}$ and prohibition of private discrimination in housing would appear to be a rational approach to eliminating the ghetto. Moreover, it is arguable that the disparity of access to and protection by local governmental

REC. S1199 (daily ed. Feb. 8, 1968) (statement of Senator Thurmond). On the other hand, Senator Mondale believed he "could explore the constitutional issue at great length, but the hearings to which I have referred amassed overwhelming and irrefutable authority establishing without doubt the constitutionality of the amendment 1 have presented to the Senate."114 Cosg. Rec. S986 (daily ed. Feb. 6, 1968). See also Hearings on the Proposed Civil Rights ACt of 1967 Before the Subcomm. on Constitutional Rights of the Senate Comm. on the Judiciary: 90th Cong., Ist Sess. (1967).

${ }^{161}$ The fourteenth amendment and the commerce clause were the two constitutional considcrations most before Congress. See, e.g., 114 Cong. Rec. S1453 (daily ed. Feb. 20, 1968); 1967 Hearings, supra note 3, at 7. Dean Pollack of the Yale Law School suggested that the thirteenth amendment lent alternative support to the constitutionality of the then pending bill. 1967 Hearings, supra, at 163.

1E2 384 U.S. 641 (1966).

1042 U.S.C. \& 1973 (Supp. 1969).

151383 U.S. 301 (1966). The argument posed in South Carolina was that in passing the Voting Rights Act, Congress had exceeded its powers in trying to enforce the mandate of the fifteenth amendment. The Court concluded that "Congress may use any rational means to effectuate the constitutional prohibitions of racial discrimination in voting." $/ d$. at 324 .

15 s 384 U.S. at 650-51.

${ }^{165}$ See. e.g., Cox, Forewrord: Constitutional Adjudication and the. Promotion of Human Rights, 80 Harv. L. Rev. 91, 102, 107 (1966). 
exists even when the commercial effects upon which it is based are minor or individually insignificant. ${ }^{178}$ In addition, the fact that the motive behind the fair housing legislation is less commercial than it is moral does not preclude constitutional reliance on the commerce clause. ${ }^{179}$ It appears, therefore, that the commerce clause provides Congress with the power to enact the Federal Fair Housing Act.

Assuming it to be constitutional, an assessment of the eventual impact of Title VIII upon segregated housing in America should be made on the basis of what the Act was intended to achieve. It has often been argued that racial prejudice is the sole cause of housing discrimination and that such prejudice and its manifestations cannot be eliminated by legislation. While all racial prejudice will certainly not yield to the dictates of Congress, it appears that much of the discrimination practiced in American housing is based on factors other than racial prejudice. ${ }^{180}$ The Fair Housing Act, by acting upon and reducing economic motives and community justifications for racial discrimination, may be expected to reduce housing segregation. The fair housing law is not a panacea for the nation's ills. On the contrary, the elimination of housing discrimination is only one aspect of the assault upon the ghetto. ${ }^{181}$ The immediate eradication of the ghetto is not a goal of Title VIII.

Moreover, the Act should be successful in reducing the tension surrounding housing discrimination. Following the enactment of the 1964 Civil Rights Act, which banned discrimination in public accommodations, there was apparently a great deal of voluntary compliance with the law. ${ }^{182}$ This was true even in those sections of the country where pre-enactment opposition was the strongest. ${ }^{183}$

Perhaps the most dramatic change the Act will bring about is in the housing industry. A major reason behind the industry's

15x Katzenbach v. McClung, 379 U.S. 294, 300 (1964); Mabee v. White Plains Publishing Co., 327 U.S. 178 (1946); Wickard v. Filburn, 317 U.S. 111 (1942); United States v. Wrightwood Dairy Co., 315 U.S. 110 (1942). See also Maryland v. Wirtz, 392 U.S. IS3. $188-93$ (1968).

179 Heart of Atlanta Motel, Inc. v. United States, 379 U.S. 241 (1964).

twa See notes $31,34,38,39$ and 41 supra and accompanying text.

1x। See 1967 Hearings. supra note 3, at 26-27 (remarks of Att'y Gen. Clark). 47-48 (remarks of HUD Sec. Weaver).

tre See, e.g., N.Y. Times, Jan. 24, 1965, at 1, col. 2; 1967 Hearings. supra note 3, at 393 (George Meany).

whe Times article was based in part upon studies made in Monroe, La., Pine Bluff, Ark., Rolling Fork, Miss., and Allendale, S.C. N.Y. Times, supra note 182. 
discrimination is the fear of loss of business. ${ }^{164}$ Real estate agents fear the loss of white customers if they serve non-white buyers, and apartment owners and builders fear losing tenants and trade if they admit non-white lessees. Title VIII has altered this competitive situation so that all businessmen are operating under the same set of rules, and there no longer is reason to fear loss of business since the disenchanted customer will have no where else to go.

The effect upon individual homeowners should be equally significant. Because a prime cause of private discrimination is submission to community pressures, ${ }^{185}$ Title VIII will now permit the homeowner greater freedom in selecting buyers in that he now can prove to his neighbors that he has no choice but to sell to whomever wants to buy. Further impetus toward voluntary compliance is provided by the fact that fair housing is now the law of the land. It defines what is proper and improper conduct and establishes a moral guideline by which the Congress believes the Nation's populace should conduct itself. The importance of the Act as a moral standard should not be minimized. Finally, the fact that actual as well as punitive damages can be invoked for noncompliance should provide some motivation toward adherence to the terms of the statute.

HUD can fulfill a vital function under the Act's directive to the Secretary to take immediate steps toward programs of education, ${ }^{186}$ for HUD may properly utilize its full resources to convince the American people that the entrance of non-white persons into previously all-white areas need not have a deleterious effect upon property values. Comprehensive and objective proof of the de minimis effect upon property values caused by Negro entrance into communities should be made available to all real estate associations and individual homeowners. ${ }^{18 \overline{7}}$

At the present time it appears very likely that HUD will be able to provide only minimal assistance to complainants. One reason that state equal employment commissions have been relatively ineffective, according to some observers, is that they characteristically remain physically removed and inaccessible to

Is See note 33 supra and accompanying text. See also letters written to Rep. Madden, 114 Co:c. RrC. H2759 (daily ed. Apr. 10, 1968).

is See notes 43-44 supra and accompanying text.

iss 42 U.S.C.A. \$ 3609 (Supp. 1969).

17 See note 42 supra and accompanying text. 
potential complainants. ${ }^{188}$ The obvious result is that many persons who have valid claims fail to go to the trouble and expense of utilizing the administrative machinery. In this context it is interesting to note that the Congress, which passed the Fair Housing Act amid much fanfare, quietly appropriated to HUD's use less than one-fifth of the funds originally requested to provide for the eight hundred and fifty field agents HUD desired to enforce and oversee the Act. ${ }^{189}$ With only two million dollars granted out of an original budget authorization of eleven million, Secretary Weaver explained that "[w]e simply cannot implement the fair housing law without more personnel. . . . Without manpower, the fair housing legislation is meaningless." 'ign

If procedural and substantive difficulties do not vitiate Title VIII, it may eventually provide an escape valve for Negro frustration. Otherwise, it can at best serve only as a temporary sedative. To at least a certain extent, however, exodus from the ghetto is now a practical possibility.

ixx Witherspoon, supra note 32, at 1191.

ins See 114 CoNG. Ri:c. SI 1398 (daily ed. Sept. 25, 1968): H9844 (daily ed. Oct. II, 1968).

1904 CONG. QTLY. AlMAANAC 465 (1968). 
